Geological Society of America

Special Paper 377

2004

\title{
General geology and geochemistry of metamorphosed Proterozoic mafic dikes and sills, Tobacco Root Mountains, Montana
}

\author{
John B. Brady \\ Department of Geology, Smith College, Northampton, Massachusetts 01063, USA \\ Heidi K. Mohlman \\ Department of Geology, Amherst College, Amherst, Massachusetts 01002, USA \\ Caroline Harris \\ Pomona College, Claremont, California 91711-6339, USA \\ Sarah K. Carmichael \\ Lisa J. Jacob \\ Department of Geology, Smith College, Northampton, Massachusetts 01063, USA \\ Wilfredo R. Chaparro \\ University of Puerto Rico, Mayaguez, Puerto Rico, 00681
}

\begin{abstract}
Just over two billion years ago, basaltic magma intruded rocks of the PonyMiddle Mountain Metamorphic Suite and the Indian Creek Metamorphic Suite that now crop out in the Tobacco Root Mountains of Montana near the northwestern margin of the Wyoming province. Numerous examples can be found of mafic dikes that crosscut layering and gneissic banding, demonstrating that the host rocks were metamorphosed to form the gneissic texture prior to intrusion of the dikes. Although many of the intrusions appear to be sills that followed compositional layering, close inspection reveals low-angle discordance in nearly every case, consistent with rotation of dikes by shearing into nearly layer-parallel orientations. The mafic dikes do not intrude the adjacent Spuhler Peak Metamorphic Suite, which we interpret to mean that the Spuhler Peak Metamorphic Suite was not present at the time of intrusion. These dikes and sills were metamorphosed along with their host rocks during the Big Sky orogeny, a major orogenic event at $1.77 \mathrm{Ga}$ that is documented in this volume. The fine-grained, garnet-bearing, rusty-weathering metamorphosed mafic dikes and sills (MMDS) generally have a distinctive appearance in the field. Some MMDS were clearly folded or boudinaged during metamorphism, but many show only weak foliation and still have sharp contacts with their host rocks. A decrease in grain size commonly occurs on the margins of the MMDS and is believed to be a metamorphic texture that developed from the chilled margins of intrusions into cold rocks.

Chemically, the MMDS are subalkaline tholeiites that have been modified by significant fractional crystallization, as evidenced by molar $\mathrm{Mg} /(\mathrm{Mg}+\mathrm{Fe})$ values that vary from 0.6 to 0.3 and $\mathrm{TiO}_{2}$ values that vary from 0.6 to $3.0 \mathrm{wt} \%$. The ratio of $\mathrm{TiO}_{2}$ to $\mathrm{P}_{2} \mathrm{O}_{5}$ is virtually constant, indicating a common origin for the MMDS and that these two components were similarly incompatible with the fractionating minerals. The weight
\end{abstract}

Brady, J.B., Mohlman, H.K., Harris, C., Carmichael, S.K., Jacob, L.K., and Chaparro, W.R., 2004, General geology and geochemistry of metamorphosed Proterozoic mafic dikes and sills, Tobacco Root Mountains, Montana, in Brady, J.B., Burger, H.R., Cheney, J.T., and Harms, T.A., eds., Precambrian geology of the Tobacco Root Mountains, Montana: Boulder, Colorado, Geological Society of America Special Paper 377, p. 89-104. For permission to copy, contact editing@geosociety.org. (C) 2004 Geological Society of America. 
percentages of both change by a factor of five, which would require crystallization and removal of $80 \%$ of the liquid if there were a single magma source. Based on the major element chemistry, plagioclase, orthopyroxene (or pigeonite), and clinopyroxene were the major fractionating phases, with little involvement of olivine. Trace element variations are consistent with this interpretation. For example, there is no clear correlation between $\mathrm{Ni}$ and $\mathrm{MgO}$, which would be expected if there were significant olivine fractionation. Measured rare earth element (REE) data for the MMDS are all at least ten times chondrite REE values. In most cases, light rare earth elements (LREEs) are enriched relative to heavy rare earth elements (HREEs). These data are consistent with a model of intrusion of the MMDS into cool, metamorphic rocks at 2.06 Ga during continental rifting of the Wyoming province. The resulting ocean basin closed at $1.77 \mathrm{Ga}$ during the Big Sky orogeny, emplacing rocks of the Spuhler Peak Metamorphic Suite and slivers of an ultramafic, orthopyroxene cumulate, deforming all units together, and metamorphosing all rocks to at least upper amphibolite facies conditions.

Keywords: fractional crystallization, subalkaline tholeiites, Wyoming province.

\section{INTRODUCTION}

One of the most striking and important features of the metamorphic rocks of the Tobacco Root Mountains is the widespread occurrence of metamorphosed mafic dikes and sills (MMDS). These fine-grained, dark rocks are easily noticed where they sharply truncate the metamorphic banding of light-colored, quartzofeldspathic gneisses (Fig. 1). From a distance, they appear to be unmetamorphosed basalt. However, upon closer examination, the presence of fine-grained garnet crystals reveals that these ancient intrusions have also been metamorphosed. Because the MMDS clearly postdate the metamorphism that produced the gneissic banding they crosscut, but predate the metamorphism that produced the garnet crystals they contain, the timing and nature of MMDS intrusion are critical features of the Precambrian history of the Tobacco Root Mountains.

The MMDS intrude the two major suites of metamorphic rocks that constitute the bulk of the Precambrian rocks of the Tobacco Root Mountains in the northwestern Wyoming province. The host rocks are (1) the Indian Creek Metamorphic Suite and (2) the Pony-Middle Mountain Metamorphic Suite. These units are described in detail by Burger (2004, this volume, Chapter 1) and throughout this volume. Monazite dating (Cheney et al., 2004b, this volume, Chapter 8) and zircon dating (Mueller et al., 2004, this volume, Chapter 9) demonstrate that these rocks were metamorphosed at $2.45 \mathrm{Ga}$ and at $1.77 \mathrm{Ga}$. The Indian Creek Metamorphic Suite consists of rocks that are clearly metasediments, including marble and iron formation, but also includes rocks that are meta-igneous, including amphibolite. The Indian Creek Metamorphic Suite rocks were called Cherry Creek metamorphic rocks by Reid (1963) and others. The Pony-Middle Mountain Metamorphic Suite consists principally of quartzofeldspathic gneisses and hornblende amphibolites. These are the rocks that Reid (1963) and others have called Pony metamorphic rocks. The MMDS do not intrude a third important rock package, the Spuhler Peak Metamorphic Suite, which is a mafic unit that consists principally of amphibolite and Ca-depleted amphibolite, with lesser quartzite and aluminous schist. These are the rocks that Gillmeister (1972) called the Spuhler Peak Formation. The map distribution of the host rocks in the central Tobacco Root Mountains is shown in Figure 2. The MMDS are too small to appear on a map of this scale, but they are widely distributed throughout the Indian Creek and Pony-Middle Mountain Metamorphic Suites. There is no persistent map-scale orientation of the MMDS because they have been deformed and reoriented along with their host rocks.

Many previous workers have recognized the unique character of the MMDS and the constraints they provide for the geologic history of the Tobacco Root Mountains. Tansley et al. (1933) observed "dark dikes and sills" that crosscut the other metamorphic rocks. Reid (1963) emphasizes the "metabasalt dikes and sills" as an important time marker in his sequence of metamorphic and deformation events. Cordua (1973) and Hanley (1975) each devote a chapter of their Ph.D. theses to the MMDS, which they call "metabasites," and both obtained several whole-rock chemical analyses of them. Vitaliano et al. (1979; see reprinted map and text accompanying this volume) show a number of the larger MMDS occurrences as "orthoamphibolites" on their geologic map of the southern Tobacco Root Mountains. Hanley and Vitaliano (1983) provide petrographic details for the "Archean mafic dikes" or "metabasites." Prismatic zircon grains within the MMDS yield a weighted mean ${ }^{207} \mathrm{~Pb} /{ }^{206} \mathrm{~Pb}$ age of $2.060 \pm 0.006$ $\mathrm{Ga}$, which is interpreted to be the age of intrusion (Mueller et al., 2004, this volume, Chapter 9). A second population of smaller, rounded zircon grains have an error-weighted mean ${ }^{207} \mathrm{~Pb} /{ }^{206} \mathrm{~Pb}$ age of $1.763 \pm 0.008 \mathrm{Ga}$, which is interpreted to be the age of the metamorphism of these dikes (Mueller et al., 2004, this volume, Chapter 9). This metamorphism is part of a regional-scale event that affected the northwestern Wyoming province, called the Big Sky orogeny by Harms et al. (2004b, this volume, Chapter 11).

We present here whole-rock chemical analyses of MMDS samples, including data for rare earth elements (REEs) and a variety of other trace elements, collected as part of Keck Geology Consortium undergraduate research projects (Brady et al., 1998). Jacob (1994) analyzed nine MMDS samples as part of a larger 

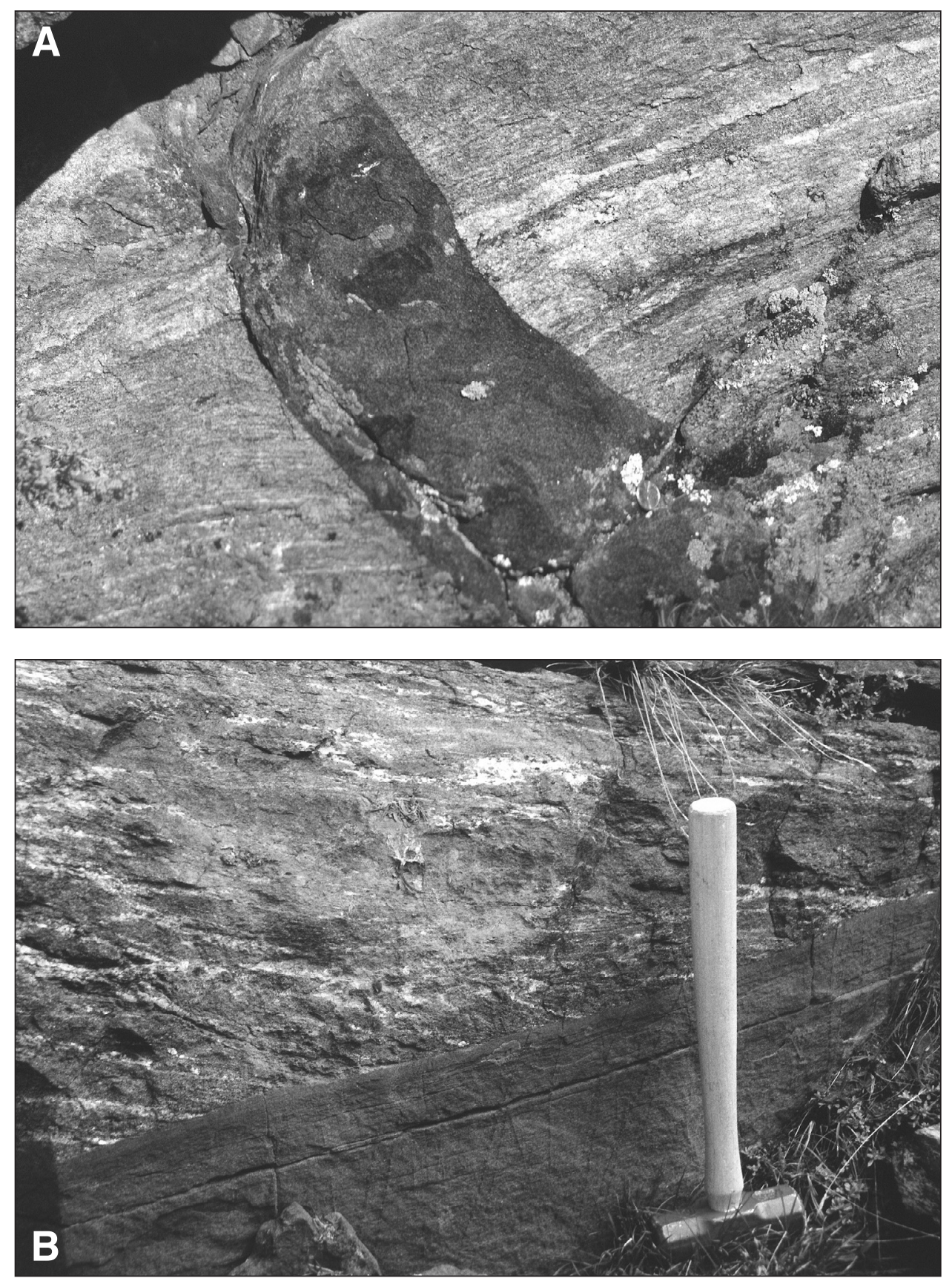

Figure 1. A: A narrow, fine-grained metamorphosed mafic dike (MMDS) cuts Indian Creek Metamorphic Suite gneissic banding in an outcrop near Ramshorn Creek in the southwestern Tobacco Root Mountains. A penny is in the lower right for scale. B: An MMDS dike of unknown thickness crosscuts Indian Creek Metamorphic Suite layering on Thompson Ridge at an angle $<30^{\circ}$. Note the weak foliation in the MMDS parallel to its contact with the Indian Creek Metamorphic Suite. Hammer is $40 \mathrm{~cm}$ high. geochemical study of the rocks in the vicinity of Noble Lake. Harris (1998) presented whole-rock chemical data for 14 MMDS samples collected at localities across the Tobacco Root Mountains. These data, along with the wet chemical analyses of Cordua (1973) and Hanley (1975), are consistent with a subalkaline, tholeiitic basalt protolith for the MMDS. The MMDS show a considerable range of enrichment in iron and incompatible elements. We argue here that the chemical variations can be attributed to extensive fractional crystallization of plagioclase, orthopyroxene, and clinopyroxene in the magmatic source of the MMDS.

\section{FIELD RELATIONS}

The MMDS of the Tobacco Root Mountains have a characteristic field appearance that permits all but the thinnest of them to be distinguished from other dark metamorphic rocks. Most MMDS features have been described by previous workers and we will use some of their words to aid this description. Perhaps the most distinctive MMDS are those dikes that "... cut across layering in surrounding gneisses at high angles" (Hanley and Vitaliano, 1983) (see Fig. 1). Indeed, because the textures and 


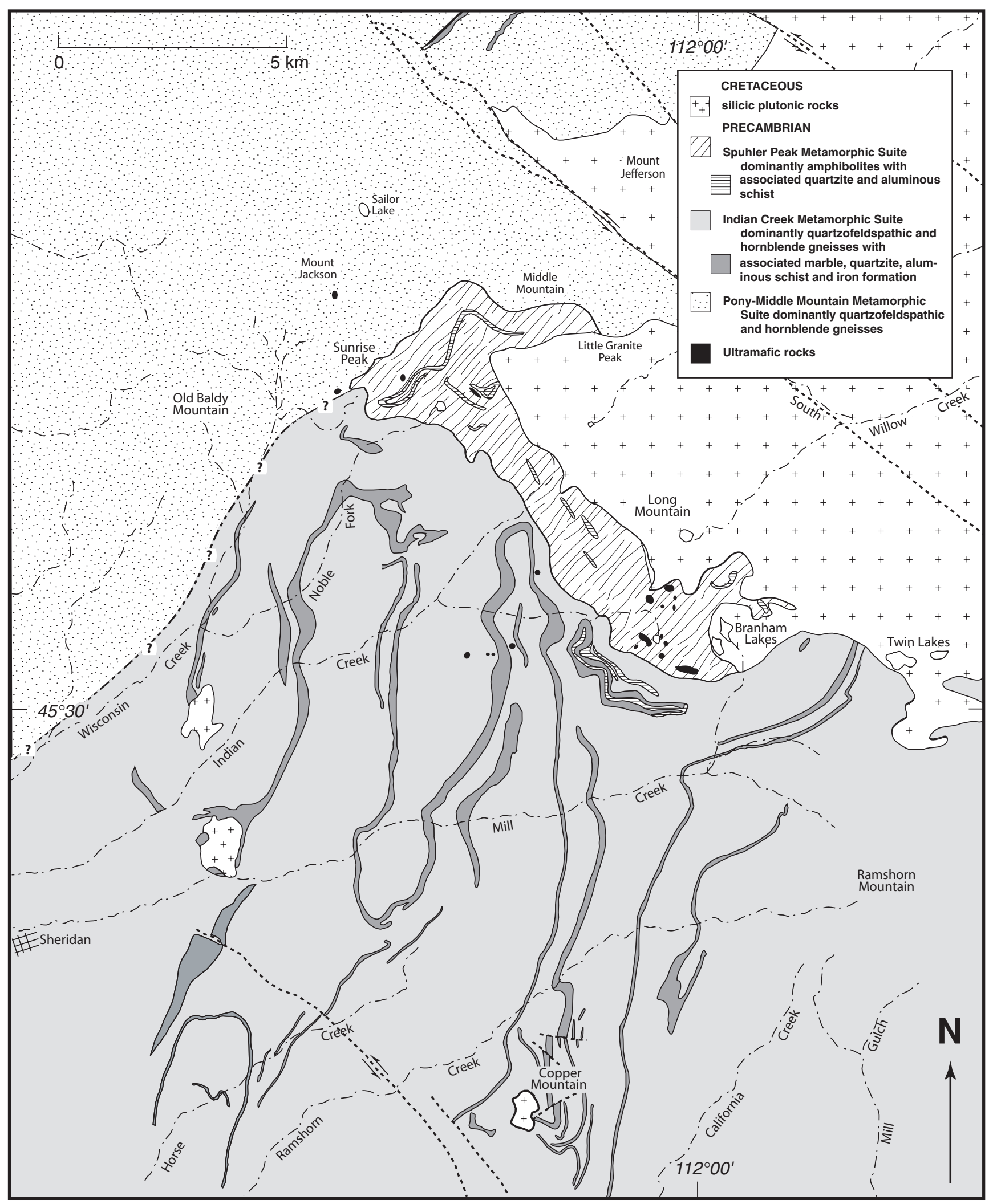

Figure 2. Geologic map of the central portion of the Tobacco Root Mountains. Modified from Vitaliano et al. (1979). 
mineralogy of MMDS that have been hydrated can be similar to those of mafic layers in the host gneisses, crosscutting contacts are the only guarantee that a mafic unit is a MMDS. This is true for sills as well as dikes. "Close examination of what appear to be sills generally reveals low-angle discordance to gneissic layering” (Hanley and Vitaliano, 1983) (see Fig. 3). "They are parallel or nearly parallel to the schistosity of the enclosing rocks, locally cutting it at angles of 1-10 " (Reid, 1963). Apparently the fracturing that permitted the intrusion of these sills was not limited to layer-parallel breaks, which is consistent with emplacement into cold rocks that had previously been metamorphosed to high grade. Rotation by shearing during metamorphism may have reduced significantly the contact angle of the MMDS, causing more of them to appear sill-like (Passchier et al., 1990, p. 79).

The MMDS “... are dark rocks, weathering a characteristic dark mottled brown. They are generally resistant to erosion and stand out in sharp relief relative to the amphibolitic and quartzofeldspathic country rock. Individual intrusives are not large; dikes rarely extend for more than $750 \mathrm{~m}$ and generally do not exceed 7-8 $\mathrm{m}$ in thickness" (Cordua, 1973, p. 94). MMDS “... are fine- to medium-grained and dark brown to black; they have granoblastic, clustered granoblastic, and microflaser textures" (Vitaliano et al., 1979). Many have distinctive, small ( $\leq 1 \mathrm{~mm}$ across) garnet crystals that are visible in hand sample and are unlike the larger and less numerous garnet crystals of host rock mafic layers. Other minerals commonly visible include white plagioclase and black clinopyroxene and hornblende. Amphibole and biotite are more abundant near the margins of the MMDS, which indicates that during metamorphism more water was able to reach the margins than the middle of the MMDS. Unlike many unmetamorphosed basalts, the MMDS do not attract a magnet; ilmenite is the major oxide phase. Modal variations are summarized in Hanley and Vitaliano (1983).
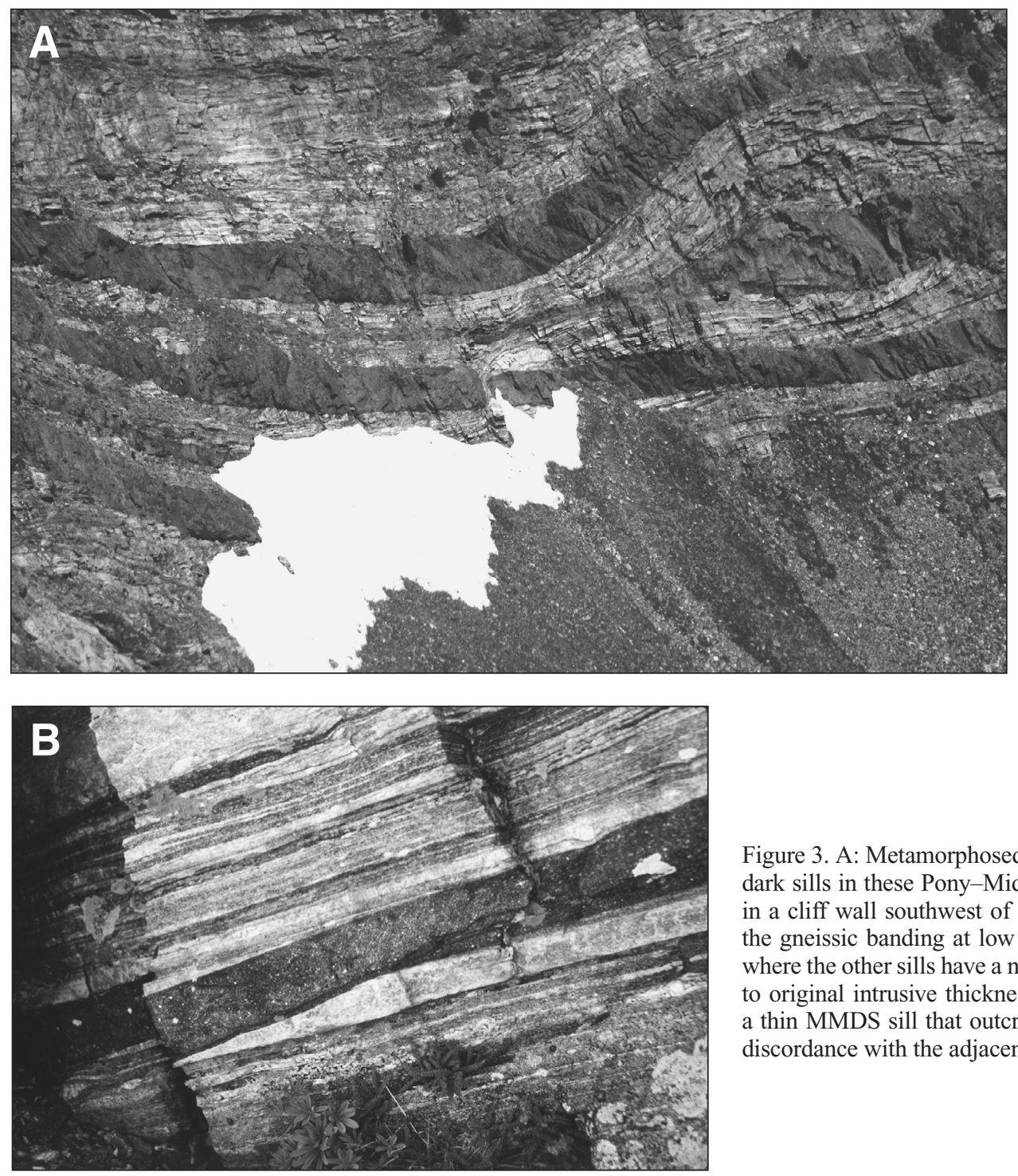

Figure 3. A: Metamorphosed mafic dikes and sills (MMDS) outcrop as dark sills in these Pony-Middle Mountain Metamorphic Suite gneisses in a cliff wall southwest of Middle Mountain. The mafic sills truncate the gneissic banding at low angles. One of the sills thins dramatically where the other sills have a nearly constant thickness, so this may be due to original intrusive thickness rather than deformation. B: Close-up of a thin MMDS sill that outcrops near Noble Lake showing a low-angle discordance with the adjacent layering. 
Although the MMDS have been metamorphosed to at least the upper amphibolite facies, remnants of primary igneous features can still be seen in outcrop. For example, contacts between the MMDS and their host rocks are invariably sharp. The margins of the MMDS are likely to be fine-grained relative to their centers, with metamorphic minerals apparently mimicking the grain size distribution in an igneous protolith with chilled margins and a coarser, more slowly cooled center (Fig. 4). Hanley and Vitaliano (1983) suggest that there are “... relict phenocrysts of plagioclase,

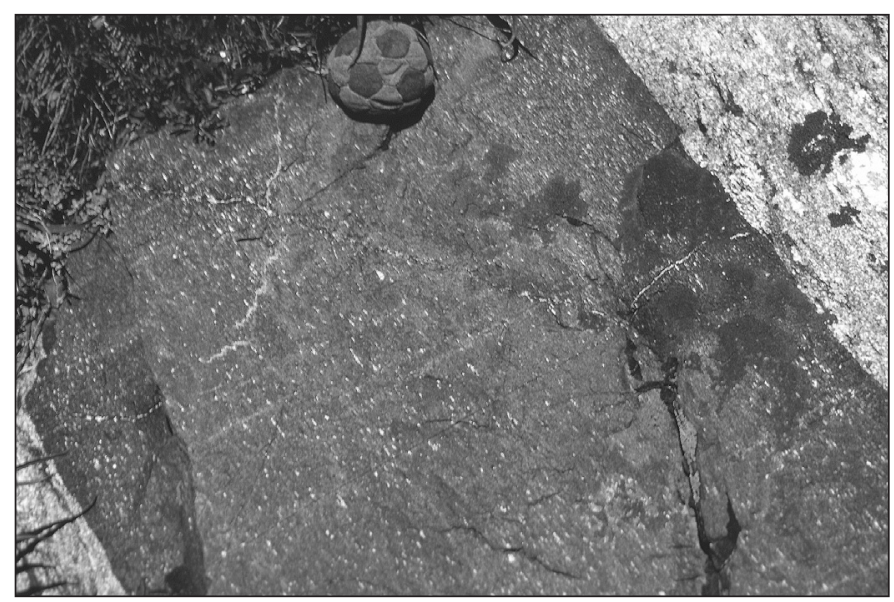

Figure 4. Narrow metamorphosed mafic dike (MMDS) from Sunrise Basin with white clusters of plagioclase crystals that are smaller near the edge of the sill and are nearly invisible in what was once a chilled margin. Note that the plagioclase clusters exhibit a lineation that is parallel to the sill boundary. The footbag in the photo is $4 \mathrm{~cm}$ wide. and less commonly of hypersthene and augite...." In several places, a second, younger MMDS has intruded an older MMDS. In all cases we examined, the younger dike was narrow and finegrained relative to the wider, coarser-grained dike being intruded (Fig. 5). These features suggest that the host MMDS was relatively cool by the time a second dike appeared. "Locally, the sills enclose xenoliths of gneiss or amphibolitic granulite" (Reid, 1963). In some of the widest MMDS, metamorphic textures mimicking primary igneous layering can be observed (Fig. 6). The preservation

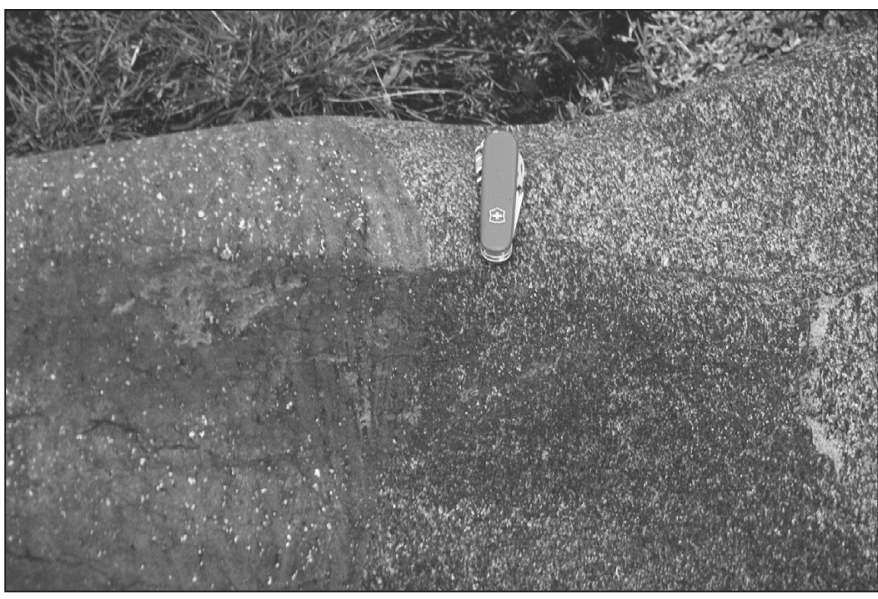

Figure 5. The contact between a coarse-grained metamorphosed mafic sill (MMDS) in Sunrise Basin and a later, fine-grained MMDS dike. Both MMDS rocks consist of the same minerals. Clusters of white plagioclase crystals are visible in both rocks, but garnet and pyroxene crystals in the fine-grained dike are too small to be seen in the photo. The contact is located just to the left of the pocketknife, which is included for scale.

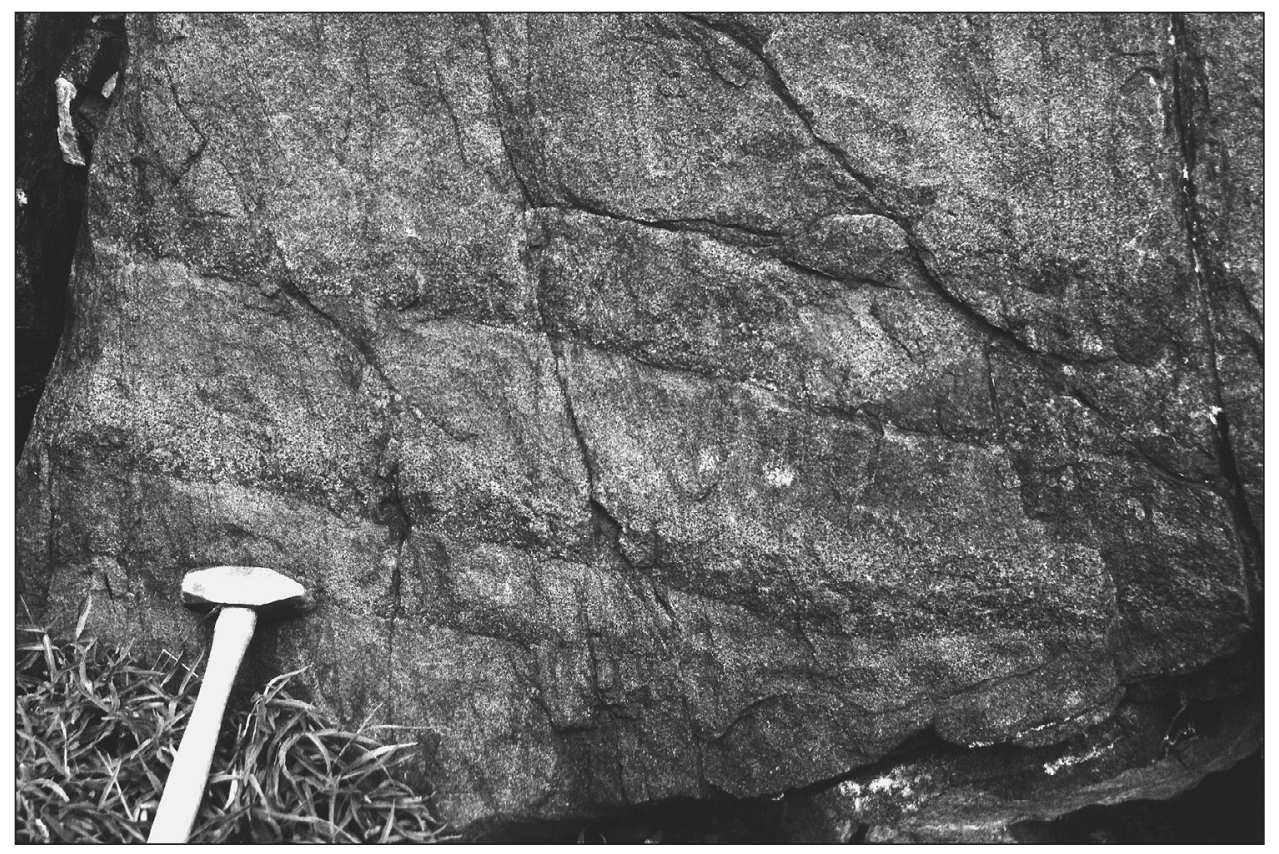

Figure 6. A layered texture in a metamorphosed mafic sill (MMDS) outcrop of a thick sill with coarse grain size in Spuhler Gulch. The layers are defined by a concentration of mafic minerals at the bottom. This texture is believed to be the result of compositional variations that resulted from crystal settling during slow crystallization of the original sill. Hammer head is $12 \mathrm{~cm}$ long. 
of igneous textures in these high-grade metamorphic rocks may be due to a lack of water during metamorphism, both in the basalt dikes and in the host rocks that were previously metamorphosed.

The igneous features described above have survived significant deformation of the MMDS during metamorphism. "Foliation and lineation exist to varying degrees in most..." MMDS (Hanley and Vitaliano, 1983) (see Fig. 4) and may be parallel to their contacts with the rocks they intruded, instead of parallel to the foliation in those rocks. These fabrics are visible in outcrop principally due to the color contrast of clusters of small, white plagioclase crystals and their matrix. "Many of the dikes have been sheared, folded, or intruded by pegmatite dikes" (Vitaliano et al., 1979) (see Figs. 7 and 8). "Many [MMDS] bodies are deformed into boudins and these are commonly stretched into laminae. Foliation within deformed [MMDS] may be folded near the ends of the boudins" (Hanley and Vitaliano, 1983). Fold axes for MMDS folds are parallel to the axes of folds in their host rocks, indicating that both the MMDS and their host rocks were deformed together during the 1.77 Ga metamorphism (see Harms et al., 2004a, this volume, Chapter 10).

Finally, MMDS intrude both the Pony-Middle Mountain and Indian Creek Metamorphic Suites, but neither we nor any previous worker has found a MMDS in the Spuhler Peak Metamorphic Suite, even though MMDS crop out within a few meters of the suite's contact (Gillmeister, 1972). The Spuhler Peak Metamorphic Suite is composed predominantly of mafic rocks and many of these rocks have chemical compositions similar to those of the MMDS (see Burger et al., 2004, this volume, Chapter 3). Nevertheless, we did not observe any crosscutting features for rocks in the Spuhler Peak Metamorphic Suite that would make them candidates to be
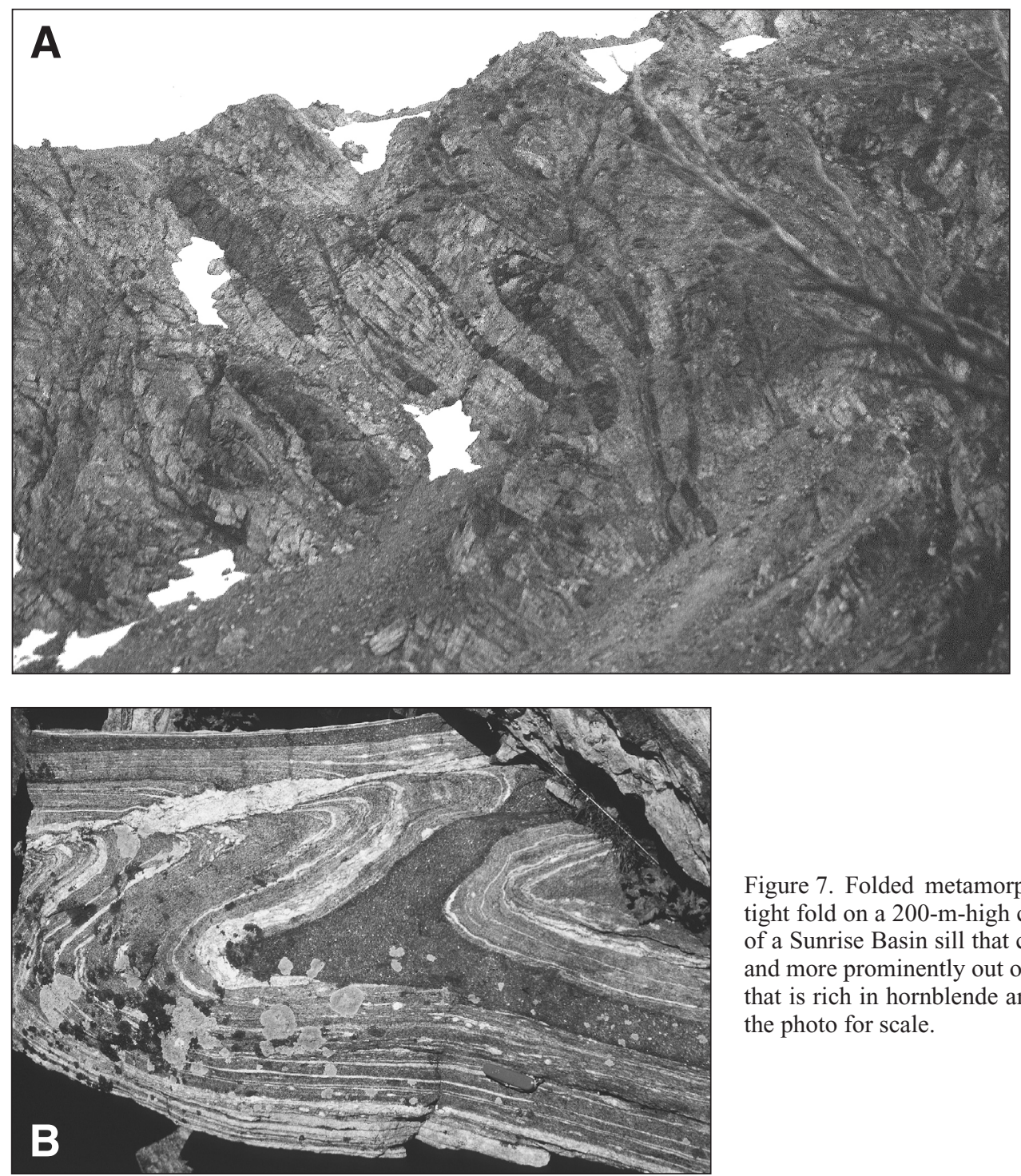

Figure 7. Folded metamorphosed mafic dikes and sills. A: A large, tight fold on a 200-m-high cliff face in Sunrise Basin. B: A small fold of a Sunrise Basin sill that crosscuts gneissic banding both in the fold and more prominently out of view along the sill. Note the dark margin that is rich in hornblende and biotite. A 10 -cm-long pocketknife is in the photo for scale. 


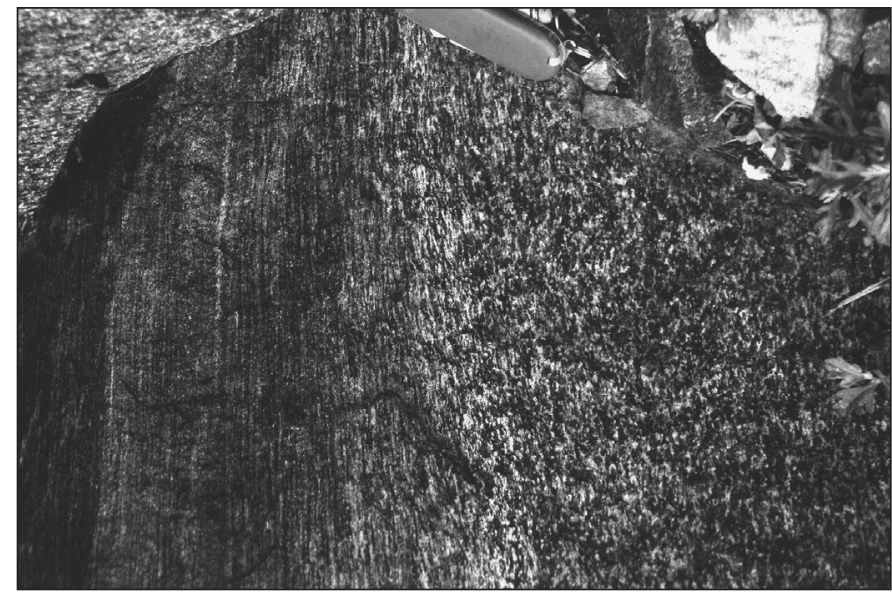

Figure 8. A coarse metamorphosed mafic dike (MMDS) from Spuhler Gulch with a fabric developed by shearing. The intensity of shearing increases to the left in the photo.

MMDS. Gillmeister (1972) suggested that the MMDS might be feeder dikes for some of the Spuhler Peak Metamorphic Suite. Although this is permitted by the chemistry of the MMDS, it is not consistent with other evidence that has been interpreted to suggest a marine setting for the origin of the Spuhler Peak Metamorphic Suite (Burger et al., 2004, this volume, Chapter 3) in contrast with the continental setting that we propose for the MMDS.

\section{WHOLE-ROCK CHEMISTRY}

The chemical compositions of the MMDS may be used to demonstrate important features of their igneous origins with implications for the history of the Tobacco Root Mountains. The available data include 23 whole-rock chemical analyses of MMDS obtained as part of our study (Jacob, 1994; Harris, 1998; Brady et al., 1998) and 16 whole-rock chemical analyses of MMDS from unpublished Ph.D. theses (Cordua, 1973; Hanley, 1975) (see Table 1). Chemical analyses were obtained using a variety of analytical techniques at several laboratories. Cordua (1973) and Hanley (1975) obtained only major element data using standard wet chemical procedures described in those theses. Major elements and some trace elements were determined using X-ray fluorescence equipment at the University of Massachusetts (Jacob, 1994) and at Franklin and Marshall College (Harris, 1998). Analytical procedures are described in Rhodes (1996) and Mertzman (2000), respectively. Many of the trace element data were determined using nuclear activation analysis at the Oregon State University Radiation Center (Harris, 1998), following procedures described at $\mathrm{http}: / /$ ne.oregonstate.edu/facilities/radiation_center/naa2.html, or at Boston College (Jacob, 1994) following procedures described in Cardoza et al. (1990). In all cases, chemical analyses are reported on an anhydrous basis with total iron given as $\mathrm{FeO}$. We believe that the robustness of the data is demonstrated by the consistency of results obtained from the different laboratories.
Based on their major element chemistry, the protoliths of the MMDS were subalkaline, tholeiitic basalts (Fig. 9). Nearly all samples have $\mathrm{SiO}_{2}$ contents between $48 \%$ and $52 \%$ by weight, with the alkali sum $\mathrm{Na}_{2} \mathrm{O}+\mathrm{K}_{2} \mathrm{O}$ less than $4 \%$. However, the molar ratio $\mathrm{MgO} /(\mathrm{MgO}+\mathrm{FeO})$ is more variable, ranging from 0.65 to 0.33 . $\mathrm{TiO}_{2}, \mathrm{P}_{2} \mathrm{O}_{5}$ and a number of trace elements (e.g., $\mathrm{Zr}$, $\mathrm{Nb}, \mathrm{Ce}, \mathrm{Nd}$ ) vary by a factor of four or more. These and other data are consistent with significant fractional crystallization in the evolution of the MMDS magmas.

Although the weight percents of both $\mathrm{TiO}_{2}$ and $\mathrm{P}_{2} \mathrm{O}_{5}$ cover a wide range of values (Table 1), the ratio $\mathrm{TiO}_{2} / \mathrm{P}_{2} \mathrm{O}_{5}$ is nearly constant for the MMDS data set (Fig. 10). We interpret this to mean that (1) the MMDS do indeed have a common magmatic origin, (2) both $\mathrm{TiO}_{2}$ and $\mathrm{P}_{2} \mathrm{O}_{5}$ are largely incompatible with the fractionating minerals, and (3) either $\mathrm{TiO}_{2}$ or $\mathrm{P}_{2} \mathrm{O}_{5}$ can be used as a normalizing component to explore quantitatively the chemical evolution of the MMDS (Pearce, 1968). For example, the Mg\# $($ molar $\mathrm{Mg} /(\mathrm{Mg}+\mathrm{Fe}))$ is plotted in Figure 11 as a function of $\mathrm{MgO} / \mathrm{TiO}_{2}$. If $\mathrm{TiO}_{2}$ is a highly incompatible component, then both the $\mathrm{Mg} \#$ and the value of $\mathrm{MgO} / \mathrm{TiO}_{2}$ should decline during fractional crystallization, which they do. Indeed, the largest value of both $\mathrm{TiO}_{2}$ and $\mathrm{P}_{2} \mathrm{O}_{5}$ is five times the smallest value, indicating that as much as $80 \%$ of the original liquid was removed by fractional crystallization if there was a single magmatic source of the MMDS. Like the Stillwater intrusion, where Fe-Ti oxides appear only in the uppermost exposed layers, it appears that Fe-Ti oxides were not stable during the fractional crystallization sampled by these dikes. We have used $\mathrm{Mg} \#, \mathrm{MgO} / \mathrm{TiO}_{2}, \mathrm{SiO}_{2} / \mathrm{TiO}_{2}$, or a largely incompatible element such as $\mathrm{Zr}$ or $\mathrm{P}_{2} \mathrm{O}_{5}$ as a measure of the degree of fractional crystallization on various composition diagrams, with essentially the same result.

Several lines of evidence can be used to identify the minerals that were removed from the MMDS source by fractional crystallization. Olivine is commonly an early crystallizing phase for basalts, but the MMDS chemistry appears to span a fractionation history that postdates the importance of olivine. For example, there is no clear correlation between $\mathrm{Ni}$ and $\mathrm{MgO}$, which would be expected if there were significant olivine fractionation (Fig. 12). Also, the $\mathrm{SiO}_{2}$ content stays approximately constant as the $\mathrm{TiO}_{2}$ content increases, instead of the increase of $\mathrm{SiO}_{2}$ that normally accompanies removal of significant olivine (Fig. 13). $\mathrm{Al}_{2} \mathrm{O}_{3}$, $\mathrm{CaO}$, and $\mathrm{MgO}$ all decrease as the $\mathrm{Mg} \#$ decreases (Fig. 14). Plagioclase fractionation is the likely cause of the decrease of $\mathrm{Al}_{2} \mathrm{O}_{3}$. Because the value of $\mathrm{CaO} / \mathrm{Al}_{2} \mathrm{O}_{3}$ is nearly constant (Fig. 15), it is unlikely that clinopyroxene is particularly important. Therefore, we are left with a low-Ca pyroxene as the best fractionation candidate to explain the variation in $\mathrm{MgO}$ (and $\mathrm{Mg} \#$ ).

The plausibility of fractional crystallization of various combinations of olivine, orthopyroxene (or pigeonite), plagioclase, and clinopyroxene was also tested using the procedures of Stanley and Russell (1989) with $\mathrm{TiO}_{2}$ as the normalizing component and $\mathrm{SiO}_{2} / \mathrm{TiO}_{2}$ as the index of fractionation. Results of several models are shown in Figure 16. Each test is designed so that if all of the variation of $\mathrm{SiO}_{2} / \mathrm{TiO}_{2}$ in the liquid could be explained 
TABLE 1. WHOLE-ROCK MAJOR AND TRACE ELEMENT ANALYSES FOR MMDS SAMPLES

\begin{tabular}{|c|c|c|c|c|c|c|c|c|c|c|c|c|c|}
\hline Source & Hanley & Harris & Cordua & Harris & Harris & Harris & Harris & Harris & Cordua & Hanley & Jacob & Cordua & Hanley \\
\hline Sample & $16-7-68-10$ & $\mathrm{CH} 4-2 \mathrm{~b}$ & E-71-624 & $\mathrm{CH} 2-3$ & $\mathrm{CH} 12-1$ & $\mathrm{CH} 10-4 a$ & $\mathrm{CH} 9-4 \mathrm{~b}$ & KJS34a & E-71-597 & $9-8-67-5$ & RB-C & E-71-479 & CC10 \\
\hline Host & PMMMS & PMMMS & ICMS & ICMS & ICMS & PMMMS & PMMMS & PMMMS & ICMS & PMMMS & ICMS & ICMS & PMMMS \\
\hline $12 \mathrm{~T}$ & $\diamond^{\S}$ & 042095 & $\diamond$ & 041762 & 041795 & 041291 & 041499 & 041645 & $\diamond$ & $\diamond$ & & $\diamond$ & $\diamond$ \\
\hline \multicolumn{14}{|c|}{ Oxide (wt\%) } \\
\hline $\mathrm{SiO}_{2}$ & 47.99 & 48.34 & 48.62 & 49.28 & 49.39 & 49.59 & 49.61 & 49.65 & 49.72 & 49.75 & 49.84 & 49.86 & 49.89 \\
\hline $\mathrm{TiO}_{2}$ & 3.00 & 2.84 & 0.82 & 1.64 & 2.02 & 1.22 & 2.05 & 1.34 & 1.15 & 0.60 & 1.89 & 2.39 & 1.27 \\
\hline${ }^{*} \mathrm{FeO}$ & 16.69 & 17.13 & 10.15 & 16.08 & 17.46 & 13.34 & 16.35 & 13.97 & 12.42 & 9.28 & 16.71 & 14.70 & 12.29 \\
\hline $\mathrm{MnO}$ & 0.29 & 0.26 & 0.17 & 0.28 & 0.28 & 0.24 & 0.27 & 0.23 & 0.22 & 0.17 & 0.28 & 0.23 & 0.23 \\
\hline $\mathrm{MgO}$ & 5.45 & 5.13 & 10.68 & 5.48 & 4.92 & 7.19 & 5.14 & 6.55 & 7.44 & 7.35 & 5.59 & 5.76 & 7.37 \\
\hline $\mathrm{CaO}$ & 9.62 & 9.84 & 11.90 & 10.08 & 9.77 & 11.16 & 9.93 & 11.01 & 10.58 & 13.80 & 9.50 & 9.82 & 11.74 \\
\hline $\mathrm{Na}_{2} \mathrm{O}$ & 2.42 & 1.59 & 1.33 & 1.85 & 2.23 & 1.85 & 2.21 & 1.96 & 1.68 & 1.52 & 2.31 & 2.53 & 2.30 \\
\hline $\mathrm{K}_{2} \mathrm{O}$ & 0.85 & 0.35 & 1.34 & 0.65 & 0.49 & 0.40 & 0.50 & 0.40 & 0.52 & 0.26 & 1.44 & 0.76 & 0.37 \\
\hline V & • & 373 & • & 347 & 315 & 280 & 315 & 258 & • & • & 424 & • & • \\
\hline $\mathrm{Cr}$ & • & 143 & • & 155 & 77 & 219 & 185 & 60 & - & • & 68 & • & - \\
\hline Co & • & 57.0 & • & 63.9 & 55.3 & 57.1 & 52.6 & 56.5 & - & • & • & • & • \\
\hline $\mathrm{Ni}$ & • & 227 & • & 268 & 167 & 219 & 121 & 101 & • & • & 60 & • & • \\
\hline $\mathrm{Cu}$ & • & 205 & • & • & 270 & 197 & 244 & 192 & • & • & • & • & • \\
\hline $\mathrm{Zn}$ & • & 151 & • & 145 & 149 & 125 & 121 & 123 & - & • & 174 & . & • \\
\hline $\mathrm{Ga}$ & • & 23.2 & • & • & 21.5 & 17.6 & 21.8 & 19.7 & • & - & - & • & • \\
\hline As & • & 3.3 & - & 2.0 & 2.4 & 2.0 & 1.6 & 1.0 & - & - & - & • & • \\
\hline $\mathrm{Se}$ & • & 1.8 & • & $<1.9$ & 0.7 & $<1.4$ & $<1.7$ & $<1.7$ & • & • & . & . & • \\
\hline $\mathrm{Rb}$ & • & 22 & • & 37 & 19 & 29 & 25 & $<9$ & - & • & - & • & • \\
\hline $\mathrm{Sr}$ & • & 246 & • & 235 & 158 & 188 & 106 & 102 & - & • & 92 & • & • \\
\hline$Y$ & • & 38 & • & . & 36 & 25 & 37 & 25 & • & • & . & • & • \\
\hline $\mathrm{Nd}$ & • & 29 & • & 16 & 22 & 10 & 12 & • & • & • & . & • & • \\
\hline $\mathrm{Sm}$ & • & 7.30 & • & 4.01 & 5.22 & 2.92 & 2.59 & 2.56 & - & - & • & • & • \\
\hline $\mathrm{Eu}$ & • & 2.23 & - & 1.28 & 1.69 & 1.03 & 0.96 & 0.91 & - & - & - & • & - \\
\hline $\mathrm{Tb}$ & - & 1.18 & - & 0.80 & 1.08 & 0.64 & 0.61 & 0.61 & - & - & - & - & - \\
\hline $\mathrm{Yb}$ & - & 3.5 & - & 2.4 & 3.5 & 2.3 & 2.5 & 2.6 & - & - & - & • & - \\
\hline Lu & - & 0.50 & - & 0.32 & 0.44 & 0.30 & 0.32 & 0.27 & - & - & - & - & - \\
\hline $\mathrm{Hf}$ & - & 5.60 & - & 2.98 & 3.99 & 2.33 & 2.03 & 1.91 & - & - & - & • & - \\
\hline $\mathrm{Ta}$ & - & 1.32 & - & 0.47 & 0.66 & 0.42 & 0.34 & 0.23 & - & - & - & • & - \\
\hline W & • & 1.9 & - & 1.0 & 1.8 & 0.9 & 0.5 & 4.2 & - & - & - & • & • \\
\hline Os (ppb) & - & $<1.1$ & - & 1.3 & $<1.3$ & $<1.3$ & $<1.1$ & $<1.2$ & - & - & - & • & - \\
\hline $\mathrm{Au}(\mathrm{ppb})$ & - & 0.01 & - & 0.01 & 0.01 & 0.02 & 0.01 & 0.00 & - & - & - & - & - \\
\hline $\mathrm{Hg}$ & • & $<0.03$ & - & 0.06 & $<0.03$ & 0.06 & $<0.03$ & $<0.03$ & • & - & - & • & • \\
\hline $\mathrm{Pb}$ & • & 9.1 & - & - & 8.9 & 8.4 & 9.1 & 8.5 & - & - & - & • & - \\
\hline Th & - & 2.8 & - & 2.0 & 1.8 & 1.1 & 1.6 & 0.7 & - & • & • & • & • \\
\hline$\underline{U}$ & • & 1.2 & • & 0.5 & 0.6 & 0.7 & 0.4 & $<0.8$ & • & • & • & • & • \\
\hline
\end{tabular}


TABLE 1. WHOLE-ROCK MAJOR AND TRACE ELEMENT ANALYSES FOR MMDS SAMPLES (continued)

\begin{tabular}{|c|c|c|c|c|c|c|c|c|c|c|c|c|c|}
\hline Source & Harris & Jacob & Hanley & Hanley & Jacob & Cordua & Harris & Jacob & Hanley & Harris & Cordua & Jacob & Hanley \\
\hline Sample & $\mathrm{CH} 9-4 \mathrm{a}$ & LJ34 & SL90B & $26-7-67-5$ & LJ16 & E-71-288 & $\mathrm{CH} 11-2$ & LJ29 & 57903 & $\mathrm{CH} 10-4 \mathrm{~b}$ & E-71-29b & LJ25 & $\begin{array}{c}16-8-67- \\
1 \mathrm{~A}\end{array}$ \\
\hline Host & PMMMS & ICMS & PMMMS & PMMMS & ICMS & ICMS & ICMS & ICMS & PMMMS & PMMMS & ICMS & ICMS & PMMMS \\
\hline $12 \mathrm{~T}$ & 041499 & 041631 & $\diamond$ & $\diamond$ & 041814 & $\diamond$ & 041623 & 041644 & $\diamond$ & 041291 & $\diamond$ & 041631 & $\diamond$ \\
\hline UTM & 504784 & 504509 & $\diamond$ & $\diamond$ & 503330 & $\diamond$ & 503347 & 504517 & $\diamond$ & 505006 & 0 & 504509 & $\diamond$ \\
\hline \multicolumn{14}{|c|}{ Oxide (wt\%) } \\
\hline $\mathrm{SiO}_{2}$ & 49.91 & 50.13 & 50.16 & 50.18 & 50.28 & 50.29 & 50.31 & 50.32 & 50.44 & 50.48 & 50.74 & 50.78 & 50.81 \\
\hline $\mathrm{TiO}_{2}$ & 1.12 & 1.90 & 0.72 & 1.57 & 1.37 & 1.30 & 0.90 & 1.14 & 1.10 & 1.11 & 2.60 & 2.10 & 0.88 \\
\hline $\mathrm{Al}_{2} \mathrm{O}_{3}$ & 13.71 & 12.56 & 14.49 & 13.06 & 14.11 & 14.14 & 13.52 & 14.45 & 15.32 & 14.17 & 14.84 & 14.23 & 14.65 \\
\hline${ }^{*} \mathrm{FeO}$ & 13.44 & 16.62 & 11.84 & 16.66 & 12.52 & 13.23 & 14.33 & 13.01 & 10.30 & 14.24 & 13.96 & 14.13 & 12.78 \\
\hline $\mathrm{MnO}$ & 0.23 & 0.28 & 0.20 & 0.28 & 0.22 & 0.23 & 0.25 & 0.25 & 0.17 & 0.24 & 0.19 & 0.27 & 0.22 \\
\hline $\mathrm{MgO}$ & 6.34 & 5.38 & 8.28 & 5.59 & 6.98 & 7.72 & 6.50 & 6.42 & 8.97 & 6.08 & 6.00 & 4.81 & 7.08 \\
\hline $\mathrm{CaO}$ & 10.61 & 8.67 & 12.16 & 9.56 & 11.50 & 10.60 & 10.77 & 10.50 & 11.47 & 10.08 & 8.62 & 8.73 & 11.62 \\
\hline $\mathrm{Na}_{2} \mathrm{O}$ & 1.97 & 2.85 & 1.86 & 2.21 & 2.44 & 1.83 & 2.01 & 2.52 & 2.00 & 2.06 & 2.75 & 3.36 & 1.89 \\
\hline $\mathrm{K}_{2} \mathrm{O}$ & 0.53 & 0.79 & 0.23 & 0.35 & 0.39 & 0.66 & 0.28 & 0.51 & 0.48 & 0.43 & 0.13 & 1.21 & 0.23 \\
\hline $\mathrm{P}_{2} \mathrm{O}_{5}$ & 0.10 & 0.18 & 0.41 & 0.12 & 0.13 & 0.09 & 0.07 & 0.10 & 0.11 & 0.11 & 0.43 & 0.25 & 0.07 \\
\hline Total & 97.97 & 99.35 & 100.35 & 99.58 & 99.94 & 100.09 & 98.95 & 99.22 & 100.36 & 99.02 & 100.26 & 99.88 & 100.23 \\
\hline \multicolumn{14}{|c|}{ Trace elements (ppm) } \\
\hline Sc & 43.8 & 45.3 & • & - & 41.6 & - & 48.7 & 41.7 & - & 40.9 & - & - & • \\
\hline V & 281 & 422 & • & • & 287 & • & 284 & 295 & • & 237 & • & 277 & • \\
\hline $\mathrm{Cr}$ & 177 & 66 & - & - & 163 & - & 154 & 87 & - & 181 & - & 36 & - \\
\hline Co & 56.7 & 50.7 & - & - & 68.4 & - & 52.1 & 55.9 & - & 53.6 & - & - & - \\
\hline $\mathrm{Ni}$ & 169 & 55 & • & - & 92 & - & 201 & 75 & - & 129 & - & 52 & • \\
\hline $\mathrm{Cu}$ & & • & • & - & • & • & 122 & - & • & 147 & • & • & • \\
\hline $\mathrm{Zn}$ & 125 & 159 & • & • & 110 & . & 132 & 187 & • & 121 & - & 149 & - \\
\hline $\mathrm{Ga}$ & • & - & • & - & • & • & 17.5 & - & • & 17.4 & - & • & • \\
\hline As & 2.5 & • & • & - & • & - & 1.7 & - & • & 2.7 & - & - & - \\
\hline $\mathrm{Se}$ & 2.0 & - & - & • & • & . & $<1.7$ & - & - & $<1.4$ & • & • & • \\
\hline $\mathrm{Rb}$ & 17 & 37 & • & - & 20 & - & 11 & 22 & • & 13 & - & • & - \\
\hline $\mathrm{Sr}$ & 141 & 160 & • & - & 330 & - & 99 & 178 & • & 200 & - & 269 & - \\
\hline Y & • & • & • & • & • & • & 22 & • & • & 27 & • & • & • \\
\hline $\mathrm{Zr}$ & 70 & 126 & • & - & 88 & • & 75 & 71 & • & 83 & • & 185 & - \\
\hline $\mathrm{Nb}$ & • & - & • & • & • & • & 3.7 & • & • & 8.2 & • & • & • \\
\hline $\mathrm{Sb}$ & 1.00 & 5.0 & • & • & 8.0 & - & 0.00 & 4.0 & • & 0.00 & • & 17.0 & • \\
\hline Cs & 1.2 & 0.2 & • & • & 0.7 & • & 0.5 & 0.4 & • & 0.3 & • & • & • \\
\hline $\mathrm{Ba}$ & 202 & 214 & • & • & 310 & • & 64 & 101 & - & 195 & - & 384 & - \\
\hline La & 8.5 & 7.7 & • & - & 11.4 & - & 3.3 & 5.6 & • & 9.6 & - & 19.0 & • \\
\hline $\mathrm{Ce}$ & 20 & 20 & • & • & 26 & • & 9 & 13 & • & 24 & • & 53 & • \\
\hline $\mathrm{Nd}$ & 14 & 13 & • & • & 15 & • & 6 & 9 & • & 12 & • & • & • \\
\hline $\mathrm{Sm}$ & 3.03 & 4.38 & - & - & 3.54 & • & 2.16 & 2.60 & - & 3.02 & • & - & • \\
\hline Eu & 1.03 & 1.47 & - & - & 1.20 & - & 0.82 & 0.97 & - & 1.07 & - & - & - \\
\hline $\mathrm{Tb}$ & 0.68 & 0.95 & - & - & 0.57 & - & 0.57 & 0.59 & - & 0.71 & - & - & - \\
\hline $\mathrm{Yb}$ & 2.5 & 4.2 & - & - & 1.9 & - & 2.3 & 1.9 & - & 2.8 & • & - & - \\
\hline $\mathrm{Lu}$ & 0.29 & 0.66 & - & • & 0.25 & • & 0.28 & 0.32 & • & 0.29 & • & - & - \\
\hline $\mathrm{Hf}$ & 2.37 & 3.69 & - & - & 2.47 & - & 1.66 & 1.84 & - & 2.56 & - & - & - \\
\hline $\mathrm{Ta}$ & 0.38 & 0.22 & - & - & 0.82 & • & 0.17 & 0.30 & - & 0.48 & - & - & - \\
\hline W & 1.6 & - & - & - & - & • & $<1$ & - & - & 1.5 & - & - & - \\
\hline Os (ppb) & 0.6 & - & - & - & - & - & 0.4 & - & - & 0.6 & - & - & - \\
\hline $\mathrm{Au}(\mathrm{ppb})$ & 0.01 & - & - & • & - & - & 0.01 & - & - & 0.01 & - & - & - \\
\hline $\mathrm{Hg}$ & $<0.03$ & - & - & - & - & - & $<0.03$ & - & - & $<0.03$ & • & - & - \\
\hline $\mathrm{Pb}$ & • & • & • & - & - & - & 5.7 & - & - & 8.0 & - & - & - \\
\hline Th & 2.0 & 1.3 & - & - & 1.2 & - & 0.5 & 0.4 & - & 1.7 & - & - & • \\
\hline$\underline{U}$ & 0.4 & • & . & • & 6.6 & • & $<1.4$ & • & . & 0.8 & - & • & . \\
\hline
\end{tabular}


TABLE 1. WHOLE-ROCK MAJOR AND TRACE ELEMENT ANALYSES FOR MMDS SAMPLES (continued)

\begin{tabular}{|c|c|c|c|c|c|c|c|c|c|c|c|c|c|}
\hline Source & Jacob & Harris & Hanley & Harris & Hanley & Harris & Harris & Hanley & Jacob & Hanley & Harris & Jacob & Jacob \\
\hline Sample & JB93-75 & $\mathrm{CH} 1-3 a$ & $20-8-67-7$ & $\mathrm{CH} 1-3 \mathrm{~b}$ & SL97 & $\mathrm{CH} 4-2 \mathrm{a}$ & $\mathrm{CH} 3-1$ & MH31 & LJ77 & $\begin{array}{c}10-8-67- \\
2 A\end{array}$ & $\mathrm{CH} 5-1$ & LJ9 & LJ7 \\
\hline Host & ICMS & PMMMS & PMMMS & PMMMS & PMMMS & PMMMS & ICMS & PMMMS & ICMS & PMMMS & PMMMS & ICMS & ICMS \\
\hline $12 \mathrm{~T}$ & 041407 & 041498 & $\diamond$ & 041498 & $\diamond$ & 042095 & 041573 & $\diamond$ & 041571 & $\diamond$ & 041810 & 041238 & 041562 \\
\hline \multicolumn{13}{|c|}{ Oxide (wt\%) } & 504570 \\
\hline $\mathrm{SiO}_{2}$ & 50.82 & 50.96 & 50.96 & 51.02 & 51.05 & 51.06 & 51.26 & 51.43 & 51.47 & 51.59 & 52.03 & 52.58 & 52.70 \\
\hline $\mathrm{TiO}_{2}$ & 1.15 & 1.06 & 0.71 & 1.00 & 1.07 & 0.78 & 0.86 & 1.23 & 1.03 & 0.81 & 1.51 & 1.84 & 1.04 \\
\hline $\mathrm{Al}_{2} \mathrm{O}_{3}$ & 15.67 & 14.76 & 14.73 & 12.80 & 14.50 & 13.85 & 14.35 & 14.00 & 13.66 & 14.93 & 13.38 & 13.79 & 14.01 \\
\hline${ }^{*} \mathrm{FeO}$ & 12.33 & 12.14 & 11.82 & 15.16 & 13.37 & 11.58 & 12.11 & 13.41 & 12.68 & 10.77 & 13.80 & 15.04 & 12.03 \\
\hline $\mathrm{MnO}$ & 0.23 & 0.21 & 0.22 & 0.28 & 0.23 & 0.20 & 0.21 & 0.25 & 0.24 & 0.19 & 0.22 & 0.25 & 0.22 \\
\hline $\mathrm{MgO}$ & 5.62 & 6.45 & 7.63 & 6.37 & 7.30 & 7.44 & 6.86 & 6.39 & 6.96 & 7.34 & 5.39 & 4.35 & 6.56 \\
\hline $\mathrm{CaO}$ & 10.31 & 10.65 & 12.01 & 10.27 & 9.32 & 11.57 & 11.16 & 10.14 & 9.96 & 11.58 & 9.12 & 8.54 & 10.64 \\
\hline $\mathrm{Na}_{2} \mathrm{O}$ & 3.00 & 2.03 & 1.83 & 1.97 & 2.48 & 1.91 & 1.92 & 2.27 & 2.70 & 2.52 & 2.14 & 2.29 & 2.18 \\
\hline $\mathrm{K}_{2} \mathrm{O}$ & 0.39 & 0.64 & 0.23 & 0.23 & 0.39 & 0.40 & 0.51 & 0.49 & 0.89 & 0.45 & 0.97 & 1.29 & 0.54 \\
\hline $\mathrm{P}_{2} \mathrm{O}_{5}$ & 0.10 & 0.11 & 0.05 & 0.08 & 0.92 & 0.07 & 0.08 & 0.12 & 0.08 & 0.07 & 0.16 & 0.21 & 0.10 \\
\hline \multicolumn{13}{|c|}{ Trace elements (ppm) } & 100.03 \\
\hline Sc & - & 39.0 & $\cdot$ & 48.5 & • & 45.6 & 43.2 & $\cdot$ & - & - & 8.3 & $\cdot$ & 46.3 \\
\hline V & 312 & 226 & • & 313 & - & 246 & 226 & • & 299 & - & 286 & 375 & 283 \\
\hline $\mathrm{Cr}$ & 59 & 245 & • & 60 & - & 30 & 180 & • & 103 & - & 13 & 29 & 101 \\
\hline Co & - & 48.4 & • & 57.9 & - & 45.3 & 46.4 & • & • & - & 42.9 & • & 55.0 \\
\hline $\mathrm{Ni}$ & 56 & 159 & • & 98 & • & 90 & 118 & $\bullet$ & 59 & • & 14 & 43 & 150 \\
\hline $\mathrm{Cu}$ & - & 100 & • & 170 & - & & 127 & • & • & - & 87 & • & • \\
\hline $\mathrm{Zn}$ & 109 & 112 & • & 129 & • & 135 & 110 & • & 112 & • & 54 & 155 & 113 \\
\hline $\mathrm{Ga}$ & • & 17.9 & • & 18.1 & • & • & 17.8 & • & • & • & 18.6 & • & • \\
\hline As & - & 5.4 & • & 1.1 & - & 1.3 & 1.0 & • & • & - & 1.8 & • & • \\
\hline $\mathrm{Se}$ & • & $<1.4$ & • & $<1.9$ & • & $<1.5$ & $<1.4$ & • & • & • & 1.9 & • & • \\
\hline $\mathrm{Rb}$ & • & 40 & • & $<9$ & • & 67 & 22 & - & • & • & 19 & • & 21 \\
\hline $\mathrm{Sr}$ & 132 & 174 & • & 98 & - & 317 & 183 & $\bullet$ & 130 & - & 177 & 151 & 390 \\
\hline$Y$ & - & 26 & • & 26 & • & - & 20 & - & • & - & 29 & • & • \\
\hline $\mathrm{Zr}$ & 72 & 74 & • & $<93$ & • & 86 & 132 & • & 60 & • & 273 & 172 & 100 \\
\hline $\mathrm{Nb}$ & - & 8.1 & • & 4.6 & • & • & 5.9 & • & • & - & 10.6 & • & • \\
\hline $\mathrm{Sb}$ & 3.0 & 0.00 & • & 0.00 & • & 0.45 & 0.00 & • & 4.0 & • & 0.00 & 8.0 & 5.0 \\
\hline $\mathrm{Cs}$ & - & 1.3 & • & 0.2 & - & 7.9 & 1.1 & • & • & • & 0.9 & • & 0.8 \\
\hline $\mathrm{Ba}$ & 63 & 268 & • & 177 & - & 768 & 163 & - & 175 & • & 357 & 367 & 310 \\
\hline La & 3.0 & 10.3 & • & 4.4 & - & 21.1 & 7.3 & • & 3.0 & - & 16.8 & 23.0 & 9.7 \\
\hline $\mathrm{Ce}$ & 19 & 21 & $\bullet$ & 13 & - & 41 & 18 & $\bullet$ & 12 & - & 37 & 48 & 23 \\
\hline $\mathrm{Nd}$ & • & 12 & • & $<6.9$ & • & 25 & 10 & • & • & • & 23 & • & 13 \\
\hline $\mathrm{Sm}$ & - & 3.04 & • & 2.48 & - & 6.49 & 2.38 & • & • & - & 4.98 & • & 3.07 \\
\hline $\mathrm{Eu}$ & • & 1.00 & • & 0.92 & • & 2.11 & 0.88 & • & • & • & 1.41 & • & 1.09 \\
\hline $\mathrm{Tb}$ & • & 0.67 & • & 0.64 & • & 1.05 & 0.53 & • & • & • & 0.80 & • & 0.58 \\
\hline $\mathrm{Yb}$ & - & 2.7 & • & 2.9 & • & 3.5 & 2.3 & • & - & - & 2.8 & • & 2.4 \\
\hline $\mathrm{Lu}$ & • & 0.34 & • & 0.37 & • & 0.49 & 0.24 & • & • & • & 0.36 & • & 0.35 \\
\hline $\mathrm{Hf}$ & • & 2.55 & • & 1.96 & • & 3.66 & 2.01 & • & • & • & 10.90 & • & 2.76 \\
\hline $\mathrm{Ta}$ & - & 0.42 & • & 0.23 & • & 0.47 & 0.29 & • & • & - & 1.17 & $\bullet$ & 0.81 \\
\hline W & - & $<2$ & • & 1.0 & • & 0.9 & 1.4 & • & • & - & 0.8 & • & • \\
\hline Os (ppb) & - & 0.8 & - & $<1.2$ & - & 0.7 & $<1.2$ & - & - & - & 0.7 & - & - \\
\hline $\mathrm{Au}(\mathrm{ppb})$ & - & 0.01 & - & 0.01 & - & 0.02 & 0.01 & - & - & - & 0.01 & - & • \\
\hline $\mathrm{Hg}$ & - & $<0.03$ & • & 0.03 & • & $<0.03$ & $<0.03$ & • & • & • & $<0.02$ & • & • \\
\hline $\mathrm{Pb}$ & • & 7.7 & • & 6.3 & • & • & 6.9 & • & - & • & 10.4 & • & • \\
\hline Th & • & 2.1 & - & 0.7 & • & 2.5 & 1.5 & • & • & • & 11.4 & • & 1.9 \\
\hline$\underline{\mathrm{U}}$ & - & 0.5 & • & $<1.7$ & - & 0.9 & 0.6 & • & - & - & 0.8 & $\bullet$ & 6.9 \\
\hline
\end{tabular}




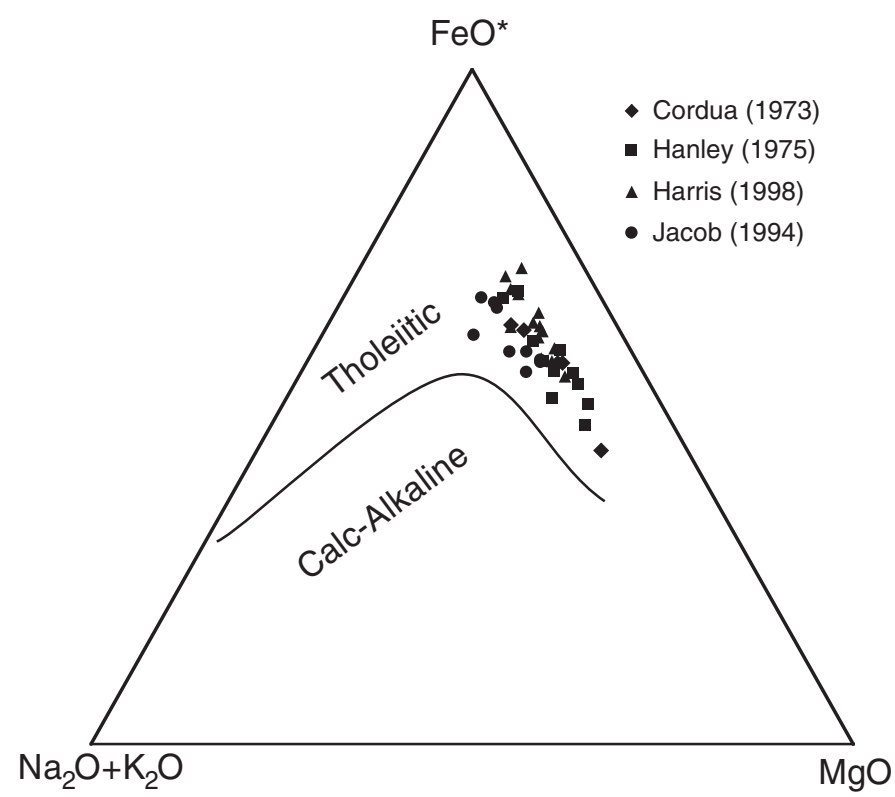

Figure 9. Metamorphosed mafic dikes and sills analyses in weight percent oxides are shown on the AFM diagram of Irvine and Baragar (1971). $\mathrm{FeO}^{*}$ means that all iron is plotted as $\mathrm{FeO}$. The data show a tholeiitic fractionation trend of iron enrichment at constant alkalis.

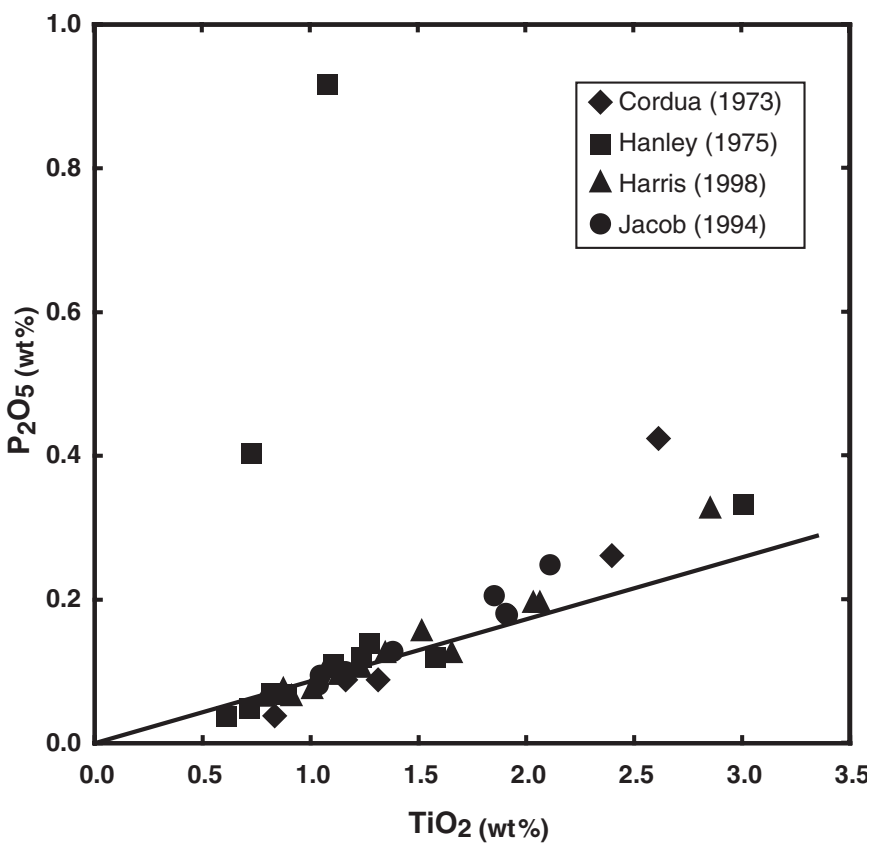

Figure 10. Weight percent $\mathrm{P}_{2} \mathrm{O}_{5}$ vs. weight percent $\mathrm{TiO}_{2}$ for the metamorphosed mafic dikes and sills samples listed in Table 1. With the exception of three samples, all fall very close to a straight line that passes through the origin. These data are consistent with both $\mathrm{TiO}_{2}$ and $\mathrm{P}_{2} \mathrm{O}_{5}$ being largely incompatible with any fractionating minerals and with $\mathrm{P}_{2} \mathrm{O}_{5}$ being slightly more incompatible than $\mathrm{TiO}_{2}$.

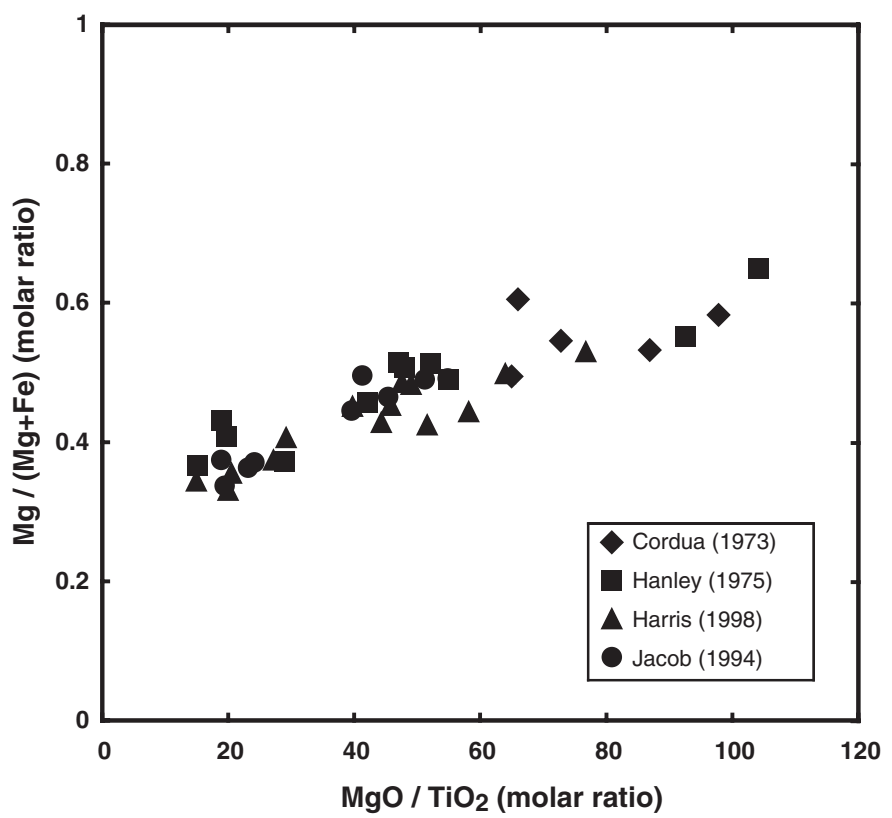

Figure 11. The $\mathrm{Mg}$, which is the molar ratio of $\mathrm{Mg}$ to $(\mathrm{Mg}+\mathrm{Fe})$, of the MMDS samples is shown as a function of $\mathrm{MgO} / \mathrm{TiO}_{2}$. A decrease in $\mathrm{MgO} / \mathrm{TiO}_{2}$ is matched by a decrease in $\mathrm{Mg} \#$, consistent with fractional crystallization of one or more $\mathrm{Mg}-\mathrm{Fe}$ silicates with $\mathrm{Ti}$ as an incompatible element.

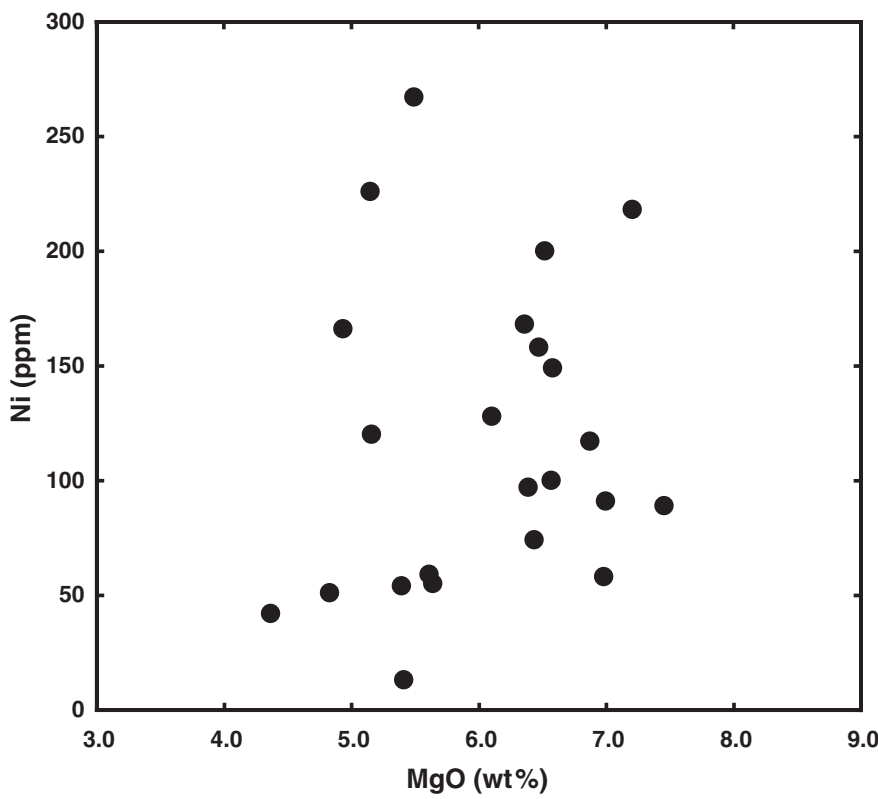

Figure 12. Ni content in parts per million is shown as a function of $\mathrm{MgO}$ content in weight percent. The absence of correlation between these numbers is interpreted to mean that olivine is not an important fractionating phase in the evolution of metamorphosed mafic dikes and sills magmas represented by these samples. 


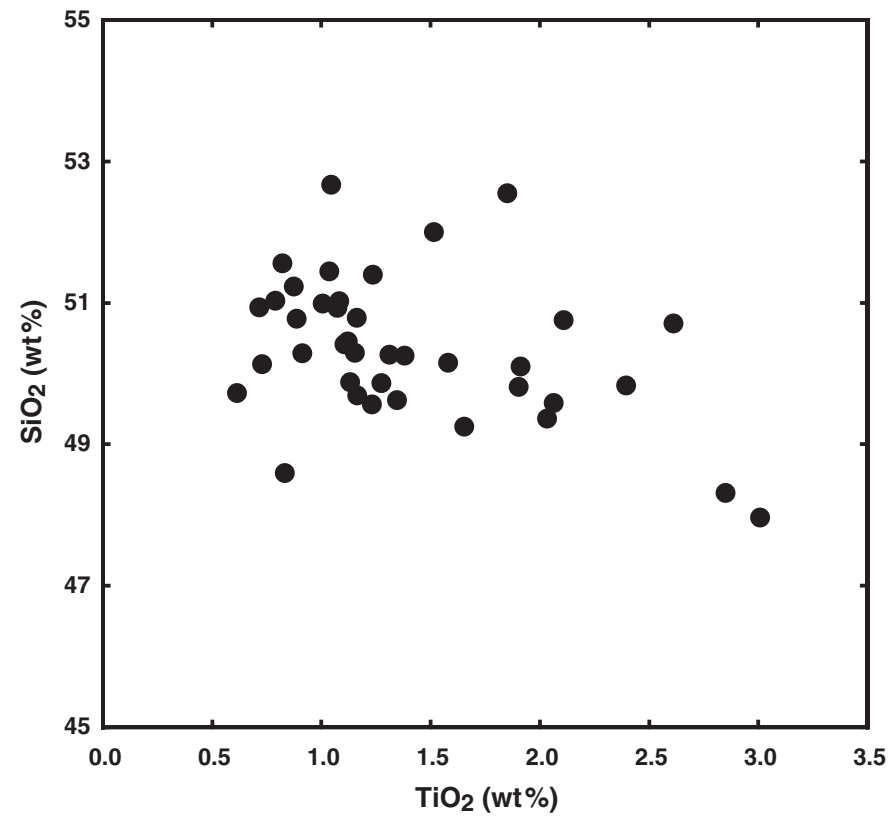

Figure 13. $\mathrm{SiO}_{2}$ content in weight percent is shown as a function of $\mathrm{TiO}_{2}$ content in weight percent. Although there is considerable scatter, the weight percent of $\mathrm{SiO}_{2}$ decreases somewhat as the weight percent of $\mathrm{TiO}_{2}$ increases during fractional crystallization. The weight percent of $\mathrm{SiO}_{2}$ should increase if olivine is a major fractionating phase.

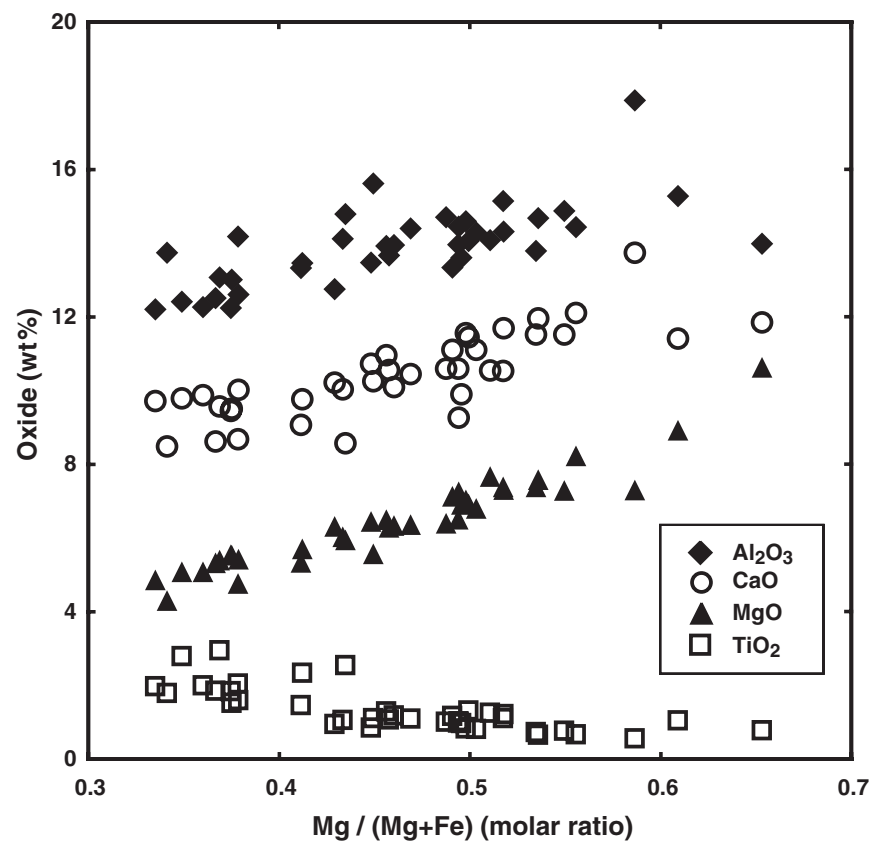

Figure 14. Weight percentages of $\mathrm{Al}_{2} \mathrm{O}_{3}, \mathrm{CaO}, \mathrm{MgO}$, and $\mathrm{TiO}_{2}$ are shown as a functions of $\mathrm{Mg} \#$ (molar $\mathrm{Mg} /(\mathrm{Mg}+\mathrm{Fe})$ ) for the metamorphosed mafic dikes and sills samples. $\mathrm{Al}_{2} \mathrm{O}_{3}, \mathrm{CaO}$, and $\mathrm{MgO}$ decrease as $\mathrm{Mg} \#$ decreases which is consistent with their removal during fractional crystallization as major components of the fractionation phases. $\mathrm{TiO}_{2}$ increases as $\mathrm{Mg} \#$ decreases, which shows that it is highly incompatible with the fractionating phases.

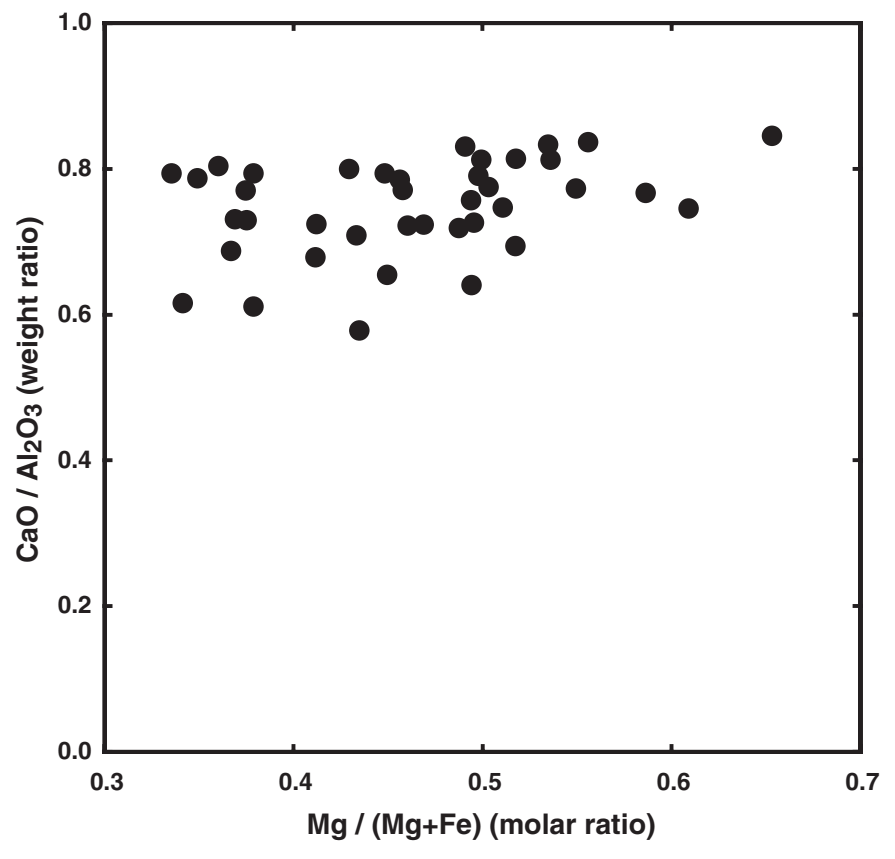

Figure 15. The $\mathrm{CaO} / \mathrm{Al}_{2} \mathrm{O}_{3}$ weight ratio is shown as a function of the $\mathrm{Mg} \#$ (molar $\mathrm{Mg} /(\mathrm{Mg}+\mathrm{Fe}))$. The value of $\mathrm{CaO} / \mathrm{Al}_{2} \mathrm{O}_{3}$ is nearly constant, decreasing only slightly as the $\mathrm{Mg} \#$ decreases during fractional crystallization. This pattern is interpreted to mean that there is only a modest amount of clinopyroxene removal from the metamorphosed mafic dikes and sills liquids.

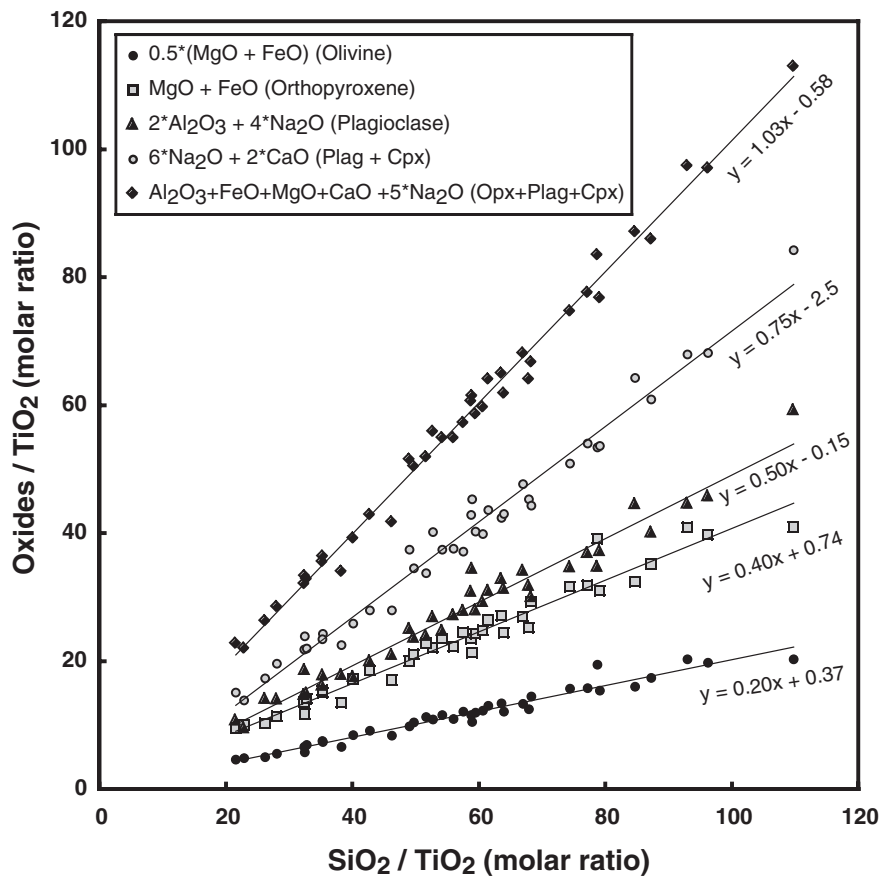

Figure 16. Pearce element ratio diagram showing several tests for fractional crystallization using $\mathrm{TiO}_{2}$ as a normalizing component for oxide molar ratios. The oxide combinations in the key are divided by $\mathrm{TiO}_{2}$ on the ordinate. The test for orthopyroxene, plagioclase, and clinopyroxene has a slope of one, meaning that all of the extensive chemical variation of $\mathrm{SiO}_{2} / \mathrm{TiO}_{2}$ can be explained by fractional crystallization of these phases. 
by the crystallization of the named minerals, the chemical data would plot on a line with a slope of one (Stanley and Russell, 1989). Fractional crystallization of olivine could explain only a small portion of the observed change in $\mathrm{SiO}_{2} / \mathrm{TiO}_{2}$ (slope $=$ 0.2 ), whereas fractional crystallization of orthopyroxene could account for $40 \%$ of the change in $\mathrm{SiO}_{2} / \mathrm{TiO}_{2}$ (slope $=0.4$ ). Plagioclase crystallization can account for half of the change in $\mathrm{SiO}_{2} / \mathrm{TiO}_{2}$ (slope $=0.5$ ). So removal of primarily orthopyroxene and plagioclase is consistent with this alternative test. A test for the combination orthopyroxene (or pigeonite) + plagioclase + clinopyroxene yields a slope of one. This result does not rule out the possibility of olivine as a fractionating phase, but it is likely that the crystallization of olivine is minor relative to the other three minerals.

Trace element data support this conclusion. The proportion of nearly all trace elements increases as $\mathrm{Mg \#}$ decreases, probably because their bulk distribution coefficients are all less than one. However, those trace elements that have higher distribution coefficients for orthopyroxene or plagioclase or clinopyroxene show less increase than elements that are less compatible with those minerals. These include Sc, Co, and Zn (orthopyroxene-GERM Kd Database http://earthref.org/databases/KDD/index.html), Ga, $\mathrm{Eu}$, and $\mathrm{Pb}$ (plagioclase - Dunn and Sen, 1994; Kravuchuk et al., 1981; Paster et al., 1974), and Sc, V, and Y (clinopyroxene-Paster et al., 1974; Jenner et al., 1994; Skulski et al., 1994). Sr variation is scattered, although it should be incorporated into plagioclase during fractionation (Matsui et al., 1977; McKenzie and O’Nions, 1991). Cr and Ni, elements that have large distribution coefficients for olivine (Nabelek, 1980; Klöck and Palme, 1988; Villemant et al., 1981), show a much larger and less systematic percentage change in value. We believe that this observation is consistent with little fractional crystallization of olivine in the range of MMDS magmas.

Analyzed REEs for the MMDS from Harris (1998) are shown on a chondrite-normalized spider diagram (Nakamura, 1974) in Figure 17. All samples have REE values that are at least ten times chondritic abundances, which is expected for mantle-derived basalts. For most MMDS samples, the LREEs are enriched relative to the HREEs. These REE trends are similar to those of continental tholeiites. Transitional to subalkalic tholeiites of the Rio Grande Rift and the East African Rift in Ethiopia have REE patterns like those of Figure 17 (Wilson, 1989, p. 360). Although fractional crystallization of orthopyroxene and clinopyroxene could be responsible for some LREE enrichment, we believe that the REE data are consistent with the continental rift setting indicated by the field relations of these dikes.

\section{DISCUSSION}

The MMDS provide key evidence for the interpretation of the geologic history of the Precambrian rocks of the Tobacco Root Mountains. They intrude the Indian Creek and Pony-Middle Mountain Metamorphic Suites, but they do not intrude the adjacent Spuhler Peak Metamorphic Suite. We interpret the absence of the MMDS in the Spuhler Peak Metamorphic Suite to mean that the suite was not present at the time of intrusion. The MMDS cut across the $2.45 \mathrm{Ga}$ foliation of the Indian Creek and Pony-Middle Mountain Metamorphic Suites (Cheney et al., 2004b, this volume, Chapter 8) and have metamorphic textures that appear to identify initial chilled margins. We interpret this evidence to mean that the MMDS were intruded into cool continental crust consisting of Indian Creek and Pony-Middle Mountain Metamorphic Suites rocks, well after the $2.45 \mathrm{Ga}$ metamorphism that produced the crosscut foliation. A plausible scenario would be intrusion during rifting that produced a passive continental margin to the Wyoming province west of the current location of the Tobacco Root Mountains. Euhedral zircons in the MMDS date their intrusion, and therefore this proposed rifting, at 2.06 Ga (Burger et al., 1999; Mueller et al., 2004, this volume, Chapter 9). Closing of the ocean basin created during the rifting led to emplacement of the Spuhler Peak Metamorphic Suite, tectonic mixing of slivers of orthopyroxene cumulate rocks that may have been produced during fractional crystallization of MMDS magmas, deformation of all units together, and the high-grade metamorphism of all units. The continental scale of this collision is documented by the upper amphibolite to granulite facies metamorphic conditions required to produce the MMDS mineral assemblage garnet + clinopyroxene + plagioclase + ilmenite + quartz \pm orthopyroxene \pm hornblende (Cheney et al., 2004a, this volume, Chapter 6). Recognizing the scale of this event, Harms et al. (2004b, this volume, Chapter 11) have called it the Big Sky orogeny. Mueller et al. (2004, this volume, Chapter 9) and Cheney et al. (2004b, this volume, Chapter 8) provide zircon and monazite ages, respectively, of 1.77 Ga for the metamorphic peak of the Big Sky orogeny.

The geochemistry of the MMDS is consistent with this interpretation. They are subalkaline, tholeiitic basalts similar to basalts

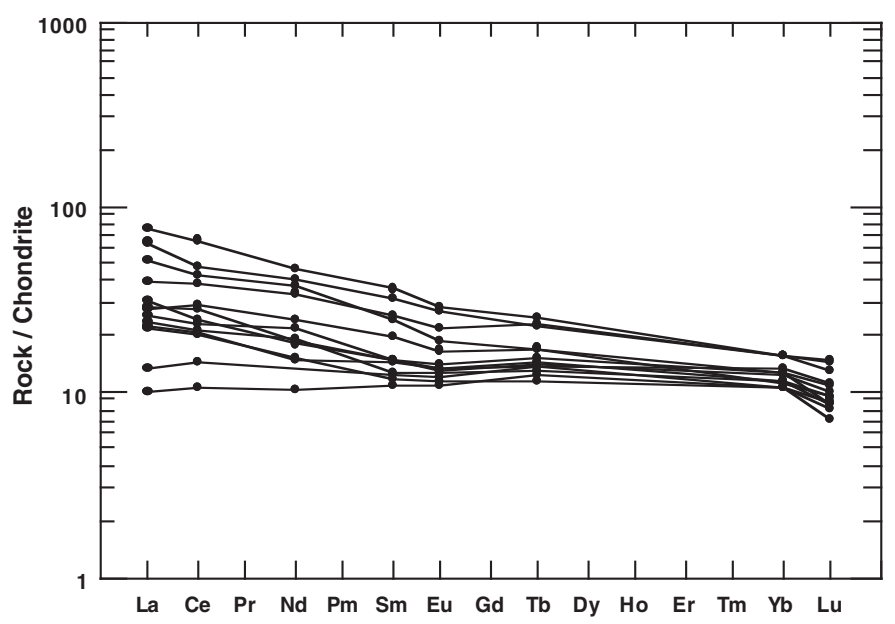

Figure 17. Chondrite-normalized rare earth element (REE) diagram for MMDS. All data are at least ten times chondrite values and most samples are enriched in the light REEs relative to the heavy REEs. 
that occur in modern continental rift settings. The continental rift appears to have persisted long enough for significant fractional crystallization of the basalts to occur and for earlier MMDS to cool prior to intrusion by later MMDS. Plagioclase and orthopyroxene appear to be the major fractionating phases responsible for the observed chemical variations. Orthopyroxene is more likely to be in the crystallization sequence of a continental tholeiite than in an oceanic tholeiite (Campbell, 1985). The higher silica observed in continental tholeiites may cause the fractionation path to move from olivine to the orthopyroxene reaction boundary, rather than to the clinopyroxene cotectic (in the system olivine-clinopyroxenesilica) as in oceanic tholeiites. Elevated pressure also can lead to orthopyroxene fractionation by shifting the orthopyroxene reaction curve away from silica on the same diagram. Neither more primitive nor more evolved alkaline magmas that may have been associated with the rifting occur in the Tobacco Root Mountains, although they might occur farther west closer to the center of the rift. Johnson et al. (2004, this volume, Chapter 4) demonstrate that meta-ultramafic rocks distributed throughout the Tobacco Root Mountains are slices of orthopyroxene-rich cumulate rocks. It is geochemically possible that these cumulates resulted from the fractional crystallization of the MMDS.

Interestingly, rifting of a similar age $(2.01 \mathrm{Ga})$ is postulated for the southeastern margin of the Wyoming province, where a more extensive suite of metamorphosed mafic dikes occurs (the Kennedy dikes), including rocks with a much more primitive composition (Condie et al., 1969; Snyder et al., 1991; Cox et al., 2000). The Kennedy dikes were also metamorphosed at ca. $1.77 \mathrm{Ga}$ during the Medicine Bow orogeny. The similarities of mafic dikes associated with continental rifting and their metamorphism during a subsequent collision is not surprising, but the near coincidence in time of these several events on opposite sides of the Wyoming province is curious indeed.

\section{ACKNOWLEDGMENTS}

The authors thank the W.M. Keck Foundation and the colleges of the Keck Geology Consortium for their financial support of this work. Stan Mertzman of Franklin and Marshall College graciously performed whole-rock, XRF analyses on short notice for Caroline Harris's senior thesis. We thank Tom Hanley for providing advice, samples, data, and helpful comments on the text. The manuscript was also improved due to an insightful review by Kevin Chamberlain and Ron Frost.

\section{REFERENCES CITED}

Brady, J.B., Carmichael, S., Burger, H.R., Harris, C., Cheney, J.T., and Harms, T.A., 1998, Thermobarometry and geochemistry of metamorphosed mafic dikes and sills (MMDS) of the Tobacco Root Mountains, Montana: Geological Society of America Abstracts with Programs, v. 30, no. 7, p. 97.

Brady, J.B., Burger, H.R., Cheney, J.T., and Harms, T.A., editors, 2004, Precambrian geology of the Tobacco Root Mountains, Montana: Geological Society of America Special Paper 377, $256 \mathrm{p}$.

Burger, H.R., 2004, General geology and tectonic setting of the Tobacco Root Mountains, in Brady, J.B., et al., eds, Precambrian geology of the Tobacco
Root Mountains, Montana: Boulder, Colorado, Geological Society of America Special Paper 377, p. 1-14 (this volume).

Burger, H.R., Brady, J.B., Cheney, J.T., Harms, T.A., Mueller, P., Heatherington, A., and Wooden, J., 1999, Evidence for a major, Early Proterozoic orogenic event in the Tobacco Root Mountains of southwestern Montana: Geological Society of America Abstracts with Programs, v. 31, no. 7, p. 177-178.

Burger, H.R., Peck, W.H., Johnson, K.E., Tierney, K.A., Poulsen, C.J., Cady, P., Lowell, J., and MacFarlane, W.A., Sincock, M.J., Archuleta, L.L., Pufall, A., and Cox, M.J., 2004, Geology and geochemistry of the Spuhler Peak Metamorphic Suite, in Brady, J.B., et al., eds, Precambrian geology of the Tobacco Root Mountains, Montana: Boulder, Colorado, Geological Society of America Special Paper 377, p. 47-70 (this volume).

Campbell, I.H., 1985, The difference between oceanic and continental tholeiites: A fluid dynamic explanation: Contributions to Mineralogy and Petrology, v. 91, p. 37-43.

Cardoza, K.D., Hepburn, J.C., and Hon, R., 1990, Geochemical constraints on the paleotectonic settings of two Late Proterozoic mafic volcanic suites, Boston-Avalon Zone, eastern Massachusetts, in Socci, A.D., et al., eds., Geology of the composite Avalon Terrane of southern New England: Geological Society of America Special Paper 245, p. 113-131.

Cheney, J.T., Brady, J.B., Tierney, K.A., DeGraff, K.A., Mohlman, H.K., Frisch, J.D., Hatch, C.E., Steiner, M.L., Carmichael, S.K., Fisher, R.G.M. Tuit, C.B., Steffen, K.J., Cady, P., Lowell, J., Archuleta, L.L., Hirst, J., Wegmann, K.W., and Monteleone, B., 2004a, Proterozoic metamorphism of the Tobacco Root Mountains, Montana, in Brady, J.B., et al., eds., Precambrian geology of the Tobacco Root Mountains, Montana: Boulder, Colorado, Geological Society of America Special Paper 377, p. 105-129 (this volume).

Cheney, J.T., Webb, A.A.G., Coath, C.D., and McKeegan, K.D., 2004b, In situ ion microprobe ${ }^{207} \mathrm{~Pb} /{ }^{206} \mathrm{~Pb}$ dating of monazite from Precambrian metamorphic suites, Tobacco Root Mountains, Montana, in Brady, J.B., et al., eds., Precambrian geology of the Tobacco Root Mountains, Montana: Boulder, Colorado, Geological Society of America Special Paper 377, p. 151-179 (this volume).

Condie, K.C., Barsky, C.K., and Mueller, P.A., 1969, Geochemistry of Precambrian diabase dikes from Wyoming: Geochimica et Cosmochimica Acta, v. 33 , no. 11 , p. $1371-1388$

Cordua, W.S., 1973, Precambrian geology of the southern Tobacco Root Mountains, Madison County, Montana [Ph.D. thesis]: Bloomington, Indiana University, $248 \mathrm{p}$

Cox, D.M., Frost, C.F., and Chamberlain, K.R., 2000, 2.01 Ga Kennedy dike swarm, southeastern Wyoming: Record of a rifted margin along the southern Wyoming province: Rocky Mountain Geology, v. 35, p. 7-30.

Dunn, T., and Sen, C., 1994, Mineral/matrix partition coefficients for orthopyroxene, plagioclase, and olivine in basaltic to andesitic systems: A combined analytical and experimental study: Geochimica et Cosmochimica Acta, v. 58, p. $717-733$.

Gillmeister, N.M., 1972, Petrology of Precambrian rocks in the central Tobacco Root Mountains, Madison Country, Montana [Ph.D. thesis]: Cambridge, Massachusetts, Harvard University, $210 \mathrm{p}$

Hanley, T.B., 1975, Structure and petrology of the northwestern Tobacco Root Mountains, Madison County, Montana [Ph.D. thesis]: Bloomington, Indiana University, $289 \mathrm{p}$.

Hanley, T.B., and Vitaliano, C.J., 1983, Petrography of Archean mafic dikes of the Tobacco Root Mountains, Madison County, Montana: Northwest Geology, v. 12, p. 43-55.

Harms, T.A., Burger, H.R., Blednick, D.G., Cooper, J.M., King, J.T., Owen, D.R., Lowell, J., Sincock, M.J., Kranenburg, S.R., Pufall, A., and Picornell, C.M., 2004a, Character and origin of Precambrian fabrics and structures in the Tobacco Root Mountains, Montana, in Brady, J.B., et al., eds., Precambrian geology of the Tobacco Root Mountains, Montana: Boulder, Colorado, Geological Society of America Special Paper 377, p. 203-226 (this volume).

Harms, T.A., Brady, J.B., Burger, H.R., and Cheney, J.T., 2004b, Advances in the geology of the Tobacco Root Mountains, Montana, and their implications for the history of the northern Wyoming province, in Brady, J.B., et al., eds., Precambrian geology of the Tobacco Root Mountains, Montana: Boulder, Colorado, Geological Society of America Special Paper 377, p. 227-243 (this volume).

Harris, C., 1998, Geochemistry of metamorphosed mafic dikes, Tobacco Root Mountains, Montana [B.A. thesis]: Claremont, California, Pomona College, $58 \mathrm{p}$. 
Irvine, T.N., and Baragar, W.R.A., 1971, A guide to the chemical classification of the common volcanic rocks: Canadian Journal of Earth Sciences, v. 8, p. $523-548$.

Jacob, L.J., 1994, A geochemical and geochronological characterization of the Indian Creek Metamorphic Suite in the Noble Lake area, southcentral Tobacco Root Mountains, southwestern Montana [B.A. thesis]: Northampton, Massachusetts, Smith College, 73 p.

Jenner, G.A., Foley, S.F., Jackson, S.E., Green, T.H., Fryer, B.J., and Longerich, H.P., 1994, Determination of partition coefficients for trace elements in high pressure-temperature experimental run products by laser ablation microprobe-inductively coupled plasma-mass spectrometry (LAM-ICP-MS): Geochimica et Cosmochimica Acta, v. 58, p. 5099-5103.

Johnson, K.E., Brady, J.B., MacFarlane, W.A., Thomas, R.B., Poulsen, C., and Sincock, M.J., 2004, Precambrian meta-ultramafic rocks from the Tobacco Root Mountains, Montana, in Brady, J.B., et al., eds., Precambrian geology of the Tobacco Root Mountains, Montana: Boulder, Colorado, Geological Society of America Special Paper 377, p. 71-87 (this volume).

Klöck, W., and Palme, H., 1988, Partitioning of siderophile and chalcophile elements between sulfide, olivine, and glass in a naturally reduced basalt from Disko Island, Greenland: Lunar and Planetary Science, v. 18, p. 471-483.

Kravuchuk, I.K., Chernysheva, I., and Urosov, S., 1981, Element distribution between plagioclase and groundmass as an indicator for crystallization conditions of the basalts in the southern vent of Tolbachik: Geochemical International, v. 17, p. 18-24.

Matsui, Y., Onuma, N., Nagasawa, H., Higuchi, H., and Banno, S., 1977, Crystal structure control in trace element partition between crystal and magma: Bulletin de la Société française de Minéralogie et Cristallographie, v. 100 , p. 324-328.

McKenzie, D., and O’Nions, R.K., 1991, Partial melt distributions from inversion of rare earth element concentrations: Journal of Petrology, v. 32, p. 1021-1091.

Mertzman, S.A., 2000, K-Ar results from the southern Oregon-northern California Cascade Range: Oregon Geology, v. 62, no. 4, p. 99-122.

Mueller, P.A., Burger, H.R., Wooden, J.L., Heatherington, A.L., Mogk, D.W., and D'Arcy, K., 2004, Age and evolution of the Precambrian crust of the Tobacco Root Mountains, Montana, in Brady, J.B., et al., eds., Precambrian geology of the Tobacco Root Mountains, Montana: Boulder, Colorado, Geological Society of America Special Paper 377, p. 181-202 (this volume).

Nabelek, P.I., 1980, Nickel partitioning between olivine and liquid in natural basalts: Henry's Law behavior: Earth and Planetary Science Letters, v. 48, p. 293-302.
Nakamura, N., 1974, Determination of REE, Ba, Fe, Mg, Na and K in carbonaceous and ordinary chondrites: Geochimica et Cosmochimica Acta, v. 38, p. 757-775.

Passchier, C.W., Myers, J.S., and Kroener, A., 1990, Field geology of highgrade gneiss terrains: Berlin, Springer Verlag, $150 \mathrm{p}$.

Paster, T.P., Schauwecher, D.S., and Haskin, L.A., 1974, The behavior of some trace elements during solidification of the Skjergaard layered series: Geochimica et Cosmochimica Acta, v. 38, p. 1549-1577.

Pearce, T.H., 1968, A contribution to the theory of variation diagrams: Contributions to Mineralogy and Petrology, v. 19, p. 142-157.

Reid, R.R., 1963, Metamorphic rocks of the northern Tobacco Root Mountains, Madison County, Montana: Geological Society of America Bulletin, v. 74, p. 293-306.

Rhodes, J.M., 1996, Geochemical stratigraphy of lava flows sampled by the Hawaiian Scientific Drilling Project: Journal of Geophysical Research, v. 101, p. $11,729-11,746$.

Skulski, T., Minarik, W., and Watson, E.B., 1994, High-pressure experimental trace-element partitioning between clinopyroxene and basaltic melts: Chemical Geology, v. 117, p. 127-147.

Snyder, G.L., Hall, R.P., Hughes, D.J., and Ludwig, K.R., 1991, Early Precambrian basic rocks of the USA, in Hall, R.P., and Hughes, D.J., eds., Early Precambrian basic magmatism: Glasgow, Blackie, p. 191-220.

Stanley, C.R., and Russell, J.K., 1989, Petrologic hypothesis testing with Pearce element ratio diagrams: Derivation of diagram axes: Contributions to Mineralogy and Petrology, v. 103, p. 78-89.

Tansley, W., Schafer, P.A., and Hart, L.H., 1933, A geological reconnaissance of the Tobacco Root Mountains, Madison County, Montana: Montana Bureau of Mines and Geology Memoir 9, $57 \mathrm{p}$.

Villemant, B., Jaffrezic, H., Joran, J.-L., and Treuil, M., 1981, Distribution coefficients of major and trace elements; fractional crystallization in the alkali basalt series of Chaine des Puys (Massif Central, France): Geochimica et Cosmochimica Acta, v. 45, p. 1997-2016.

Vitaliano, C.J., Burger, H.R., Cordua, W.S., Hanley, T.B., Hess, D.F., and Root, F.K., 1979, Explanatory text to accompany the geologic map of the southern Tobacco Root Mountains, Madison County, Montana: Geological Society of America Map and Chart Series MC31, scale 1:62,500, 1 sheet, 8 p. text.

Wilson, M., 1989, Igneous petrogenesis: London, Unwin Hyman, 466 p.

Manuscript Accepted by the Society September 12, 2003 